*ak RMIS View/Frint Document Cover Sheet tow

This document was retrieved from the Documentation and Records Manaqement (DRM) ISEARCH System. It is intended for Information only and may not be the most recent or updated version. Contact a Document Service Center (see Hanford Info for locations) if you need additional retrieval information.

Accession \#: D196034188

Document \#: SD-SNF-TI-016

Title/Desc:

DEVELOPMENT OF DESIGN BASIS CAPACITY FOR SNF PROJECT SYSTEMS

Pages: 38 
Sta.4 (6)

FEB 271996 ENGINEERING DATA TRANGMITTAL

Peqe 1 of 1

1. EOT NO 612992

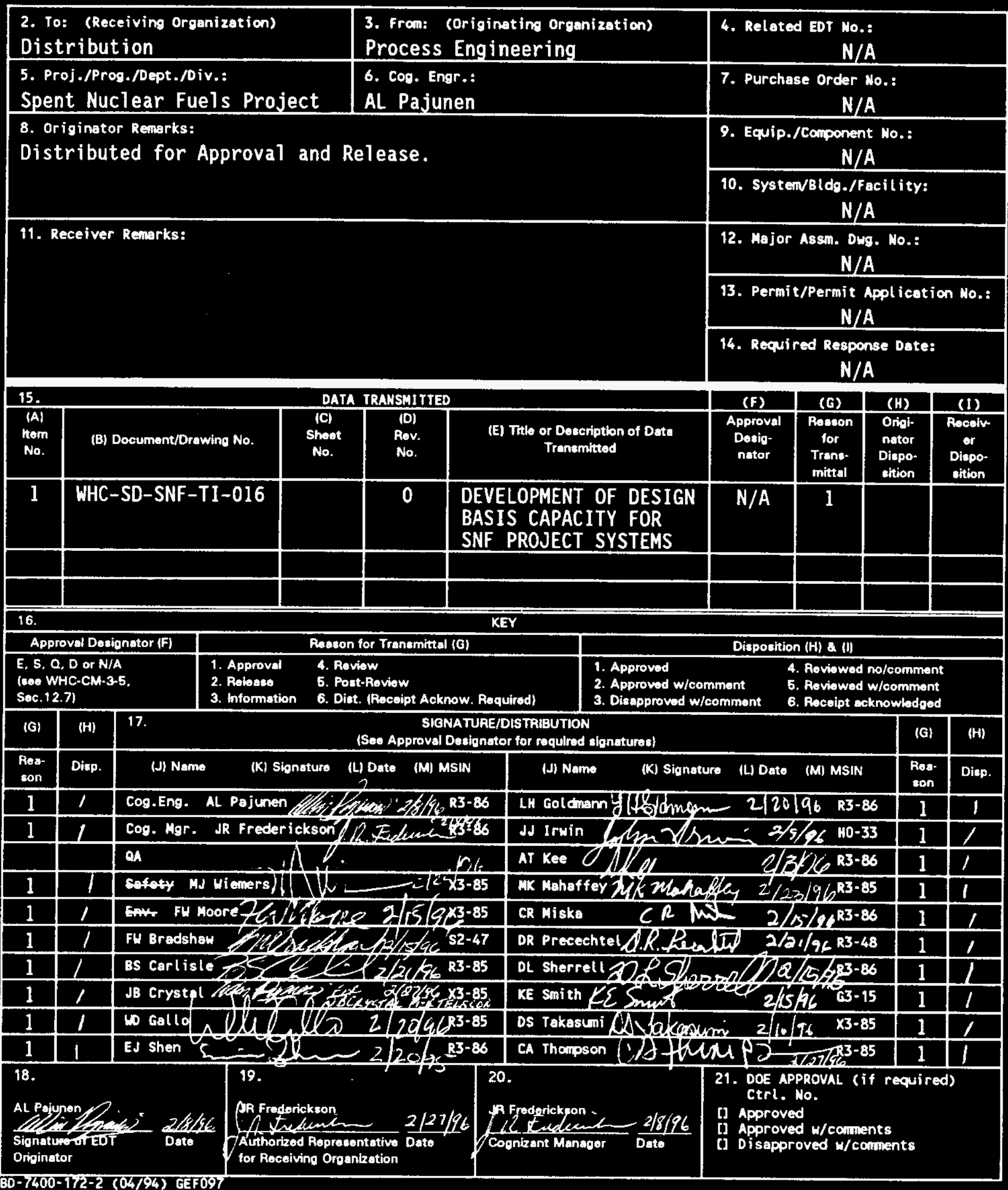




\title{
Development of Design Basis Capacity for SNF Project Systems
}

\author{
A. L. Pajunen \\ West inghouse Hanford Company, Richland, WA 99352 \\ U.S. Department of Energy Contract DE-AC06-87RL10930 \\ $\begin{array}{lll}\text { EDT/ECN: } & 612992 & \text { UC: UC-510 } \\ \text { Org Code: } & 2 \text { C400 } & \text { Charge Code: LB014 } \\ \text { B\&R Code: } & \text { EW3135040 } & \text { Total Pages: } 35 \text { S4 Eme } 2 / 2 \text { T/Th }\end{array}$
}

Key Words: Spent Nuclear Fuel, Capacity, Design Basis

Abstract: An estimate of the design basis capacity for Spent Nuclear Fuel Project systems producing Multi-Canister Overpacks is developed based on completing fuel processing in a two year period. The design basis capacity for systems relates the desired annual processing rate to potential operating inefficiencies which may be actually experienced to project a design capacity for systems. The basis for estimating operating efficiency factors is described. Estimates of the design bas is capacity were limited to systems actually producing the MultiCanister Overpack. These systems include Fuel Retrieval, $\mathrm{K}$ Bas in SNF Vacuum Drying, Canister Storage Building support for Staging and Storage, and Hot Vacuum Conditioning. The capacity of other systems are assumed to be derived from these system capacities such that systems producing a Multi-Canister Overpack are not constrained.

TRADEMARK DISCLAIMER. Reference herein to any specific commercial product, process, or service by trade name, tradenark, manufacturer, or otherwise, does not necessarily constitute or imply its endorsement, recommendation, or favoring by the United States Goverment or any agency thereof or its contractors or subcontractors.

Printed in the United States of America. To obtain copies of this document, contact: HHC/BCS Document Control Services, P.0. Box 1970, Mailstop H6-08, Richland wA 99352, Phone (509) 372-2420; Fox (509) 376-4989.
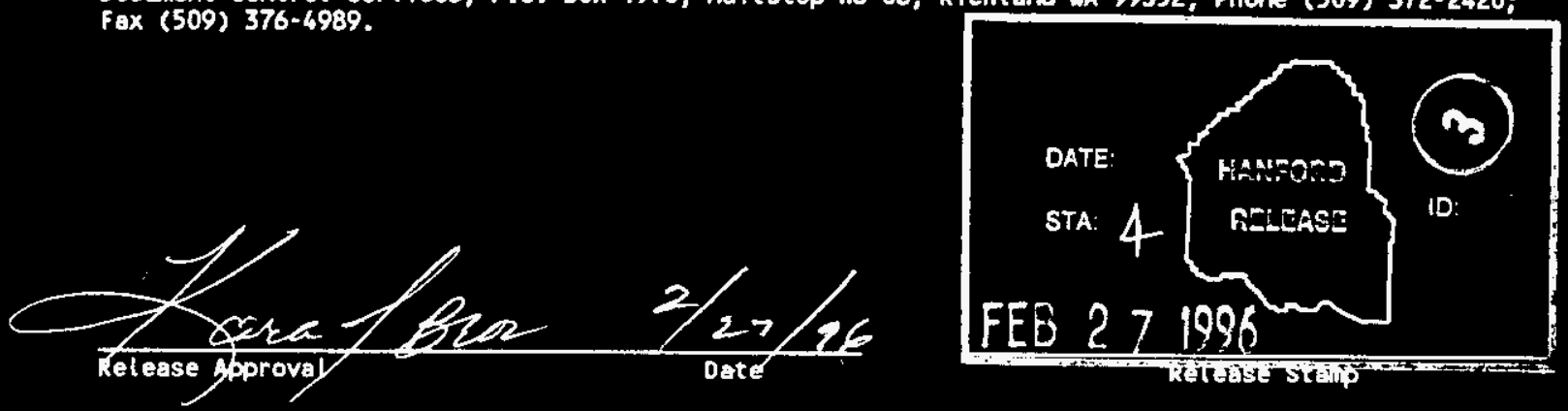

Approved for Public Release 


\author{
WHC-SD-SNF-TI-016, Rev. 0 \\ DEVELOPNENT OF DESIGN BASIS CAPACITY FOR SNF PROJECT SYSTEMS
}

\title{
EXECUTIVE SUNMARY
}

The design basis capacity for Spent Nuclear Fuel Project systems to complete removal of $K$ Basin fuel was evaluated to estimate the excess capacity which should be provided by system designs to address potential operating inefficiencies. The analysis provides an integrated evaluation of average capacity requirements for project systems from a common basis. This common basis will be updated as the project matures to reflect changes in the Project Baseline. Conversion of the average capacities to an "instantaneous" design capacity required for each system was found to be configuration dependent. Further definition of the system of queues and parallel process lines incorporated in designs is required before the "instantaneous" design capacity can be defined as a requirement for each process system.

The evaluation is based on producing a total of 400 Multi-Canister Overpacks (MCOS), or 200 MCOS from each basin, estimated from fuel piece count data and an assumed fuel piece MCO loading. The analysis uses an overall operating schedule consistent with the January 1996 Integrated Process Strategy change request (WHC, 1996a) as a basis for system production periods. This basis allows two years for removal of fuel from the KW Basin and 1.75 years for removal of KE Basin fuel. Systems common to both basins are assumed to operate for two years.

The average capacity required for systems is influenced by allocations for a process operation learning curve and the selected shift schedule for performing operations. A six month learning curve to achieve the full capacity was assumed as a basis for KW Basins systems and systems common to both basins. The learning curve for KE Basins systems (start up lags KW Basin) was assumed shortened to three months. Average capacities required for systems are dependent on the planned operating philosophy. A combination of 5 day per week and 7 day per week operations were assumed, consistent with staffing plan assumptions (WHC, 1996C). Table ES-1 summarizes the operating schedule and required average capacity for Spent Nuclear Fuel Project (SNFP) systems handling Multi-Canister Overpacks of fuel.

A Total Operating Efficiency (TOE) factor was developed to address the potential for lost operating time within an available operating day. This lost operating time is compensated for by selecting an increased capacity during design. The TOE specific to major systems was estimated by decomposing the operating efficiency into five factors.

\footnotetext{
- $\quad$ Processing Efficiency

- Product Rework

- Work Environment

- Equipment Downt ime

- Accountability Downtime
} 
The efficiency factors were adjusted for each system based on the locations and type of activity performed. The results of the TOE estimate are summarized in Table ES-2 for the major SNFP systems. These estimates represent qualitative assessments of each factor and are highly dependent on the degree of conservatism desired to address potential operating inefficiencies.

Application of the operating efficiency to the average capacity was found to be dependent on the system configuration (i.e., the number of parallel systems used in the process design and the location of queues which effectively isolate systems from delays in other systems). Due to uncertainty in configuration changes which may develop with more detailed design, the design capacity required for each system can not be established as a requirement at this time. The design capacity must be evaluated during design efforts to configuration.

Design capacities were estimated based on the current concept for system configuration shown in Figure ES-1. These estimates provide an indication of the design capacity which will be ultimately specified when design configurations have matured. The capacity estimates and equivalent cycle times to process a MCO through a single station within the system are summarized in Table ES-3. Each system capacity relies on the existence of the queues indicated on Figure ES-1 for the capacity estimate to be valid. While dependent on system TOEs, one example calculation estimates the design capacity for two systems could be doubled if the intervening queue was el iminated, indicating the importance of queues in defining capacity requirements. 
WHC-SD-SNF-TI-016, Rev. 0

\section{Table ES-1. Average Capacities Required for Spent Nuclear Fuel Project Systens}

\begin{tabular}{|c|c|c|c|c|c|}
\hline \multirow[t]{2}{*}{ Systens } & \multirow{2}{*}{$\begin{array}{l}\text { Sustained } \\
\text { Capacity" } \\
\text { (rico/Yr) }\end{array}$} & \multicolumn{2}{|c|}{ Operat ing Philosophyt" } & \multirow{2}{*}{$\begin{array}{l}\text { Required } \\
\text { Averege } \\
\text { Cepacity } \\
\text { (uco/ev day) }\end{array}$} & \multirow{2}{*}{$\begin{array}{c}\text { Averege } \\
\text { Capacity, } \\
\text { Rounded } \\
\text { (nco/av day) }\end{array}$} \\
\hline & & $\begin{array}{c}\text { Operat ing Doys } \\
\text { per Heek }\end{array}$ & av doy/Yr & & \\
\hline $\begin{array}{l}\text { KU Basin Systens: } \\
\text { - KH Fuel Retrieval } \\
\text { - KU Cask Loadin/Lodout }\end{array}$ & 119 & $\begin{array}{l}5 \\
5\end{array}$ & $\frac{250}{250}$ & $\begin{array}{l}0.48 \\
0.48\end{array}$ & $\begin{array}{l}0.5 \\
0.5\end{array}$ \\
\hline $\begin{array}{l}\text { KE Basin Systens: } \\
\text { - KE Fuel Retrieval } \\
\text { - KE Cask Loadin/Lodout }\end{array}$ & 128 & $\begin{array}{l}5 \\
5\end{array}$ & $\frac{250}{250}$ & $\begin{array}{l}0.51 \\
0.51\end{array}$ & $\begin{array}{l}0.5 \\
0.5\end{array}$ \\
\hline $\begin{array}{l}\text { Systens Common to Both Basins } \\
\text { through CSB Staging: } \\
\text { - Cold Yacum Drying } \\
\text { - Cask Transport } \\
\text { - CSB MCO/Cask Loadin/Loadout } \\
\text { - CSE/MHM Transfer to Staging }\end{array}$ & $\begin{array}{l}247 \\
247 \\
247 \\
247\end{array}$ & $\begin{array}{c}7 *+* \\
5 \\
5 \\
5\end{array}$ & $\begin{array}{l}250 \\
250 \\
250 \\
250\end{array}$ & $\begin{array}{l}0.99 \\
0.99 \\
0.99 \\
0.99\end{array}$ & $\begin{array}{l}1.0 \\
1.0 \\
1.0 \\
1.0\end{array}$ \\
\hline $\begin{array}{l}\text { Systems Common to Both Basins } \\
\text { after CSB Staging: } \\
\text { - CSB/MHM to Conditioning } \\
\text { - CSB/MHM to Storage } \\
\text { - Hot Vacuun Conditioning }\end{array}$ & $\begin{array}{l}\frac{237}{237} \\
237\end{array}$ & $\begin{array}{l}7 \\
7 \\
7\end{array}$ & $\begin{array}{l}365 \\
365 \\
365\end{array}$ & $\begin{array}{l}0.65 \\
0.65 \\
0.65\end{array}$ & $\begin{array}{l}0.65 \\
0.65 \\
0.65\end{array}$ \\
\hline
\end{tabular}

Note: - - Sustained capacity based on six month KU Basin learning curve, three month KE Bas in learning curve, and six month learning curve for systens comon to both basins after CSB staging.

** - Operating philosophy consistent with WHC, 1996c. ov day = available days

*** - The current staffing plan is based on 7 day per week operation for cold vacum drying to support multi-day cycle times but effective days of operation each year assumed limited to 250
days/year due to feed production constraints by basin systems. 
WHC-SD-SNF-TI-016, Rev. 0

Table ES-2. Total Operating Efficiencies Estimated for Spent Nuclear Fuel Project Systems

\begin{tabular}{|c|c|}
\hline System & Single System Oarrating Efficiency \\
\hline Debris Renoval & $48 x$ \\
\hline Sludge Renoval & $48 x$ \\
\hline Water Treatment & $95 \times$ \\
\hline Fuel Retrieval & $43 x$ \\
\hline $\begin{array}{l}\text { Cask Loadin/Loadout } \\
\text { (includes NCo Welding) }\end{array}$ & $48 x$ \\
\hline K Basin SNF Vacum Drying & $51 x$ \\
\hline Cask Transportation & $100 x *$ \\
\hline $\begin{array}{l}\text { Canister Storage Building } \\
\text { MCO/Cask Loadin/Loadout }\end{array}$ & $68 x$ \\
\hline $\begin{array}{l}\text { Canister Storage Building } \\
\text { HCO Transfers in } \\
\text { MCO Handl ing Mach ine }\end{array}$ & $71 x$ \\
\hline Hot Vacuun Conditioning & $51 x$ \\
\hline
\end{tabular}

* - Water Treatment and Cask Transportation systems were assumed to be high reliability activities when considering their impacts on other systens.

Table ES-3. Estimated Design Capacity for Spent Nuclear Fuel Project Systems (Based on Configuration in Figure ES-1)

\begin{tabular}{|c|c|c|c|}
\hline System & $\begin{array}{c}\text { Estimated System } \\
\text { Design Capacity } \\
\text { (Mco/operating day) }\end{array}$ & $\begin{array}{l}\text { Number of Parallel } \\
\text { stations in System }\end{array}$ & $\begin{array}{c}\text { Haximum Allowable Cycle } \\
\text { Time for Each Station to } \\
\text { Produce One MCO } \\
\text { (Hr) }\end{array}$ \\
\hline $\begin{array}{l}\text { KE Basin systens: } \\
\text { KE Basin Fuel Retrieval } \\
\text { KE Basin Cask Losdin/Loodout }\end{array}$ & $\begin{array}{l}0.8 \\
1.0\end{array}$ & $\frac{2}{1}$ & $\frac{60}{24}$ \\
\hline $\begin{array}{l}\text { KU Basin Systens: } \\
\text { KW Basin Fuel Retrieval } \\
\text { KW Basin Cask Loadin/Loadout }\end{array}$ & $\begin{array}{l}0.8 \\
1.0\end{array}$ & 2 & $\begin{array}{l}60 \\
24\end{array}$ \\
\hline $\begin{array}{l}\text { Systems Common to Both Basins: } \\
\text { K Basin SNF Vacum Drying } \\
\text { Cask Transport to CSB } \\
\text { CSB NCo Receipt from Basins } \\
\text { mo /HW Transfers within the CSB } \\
\text { Hot Vacum Conditioning }\end{array}$ & $\begin{array}{l}1.0 \\
2.0 \\
2.0 \\
4.0 \\
0.7\end{array}$ & $\begin{array}{l}6 \\
1 \\
1 \\
6\end{array}$ & $\begin{array}{c}140 \\
12 \\
12 \\
6 \\
205\end{array}$ \\
\hline
\end{tabular}

Note: These estimates represent a prel ininary indication of the required desion capacity based on an assuned configuration for the spent Nuclear Fuel Project systens. Required design capacities will be modified as the configuration is changed during the design process. 
Figure ES-1. Schematic of SNFP Systems Used for Design Capacity Estimates

$<$

$\begin{array}{cc}\begin{array}{c}\text { Fuel } \\ \text { Retrieval }\end{array} & \begin{array}{c}\text { Cask } \\ \text { Loadin/Loadout, } \\ \text { Includes MCO Welding }\end{array}\end{array}$

(a) for destipn capacty to be valits.

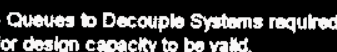

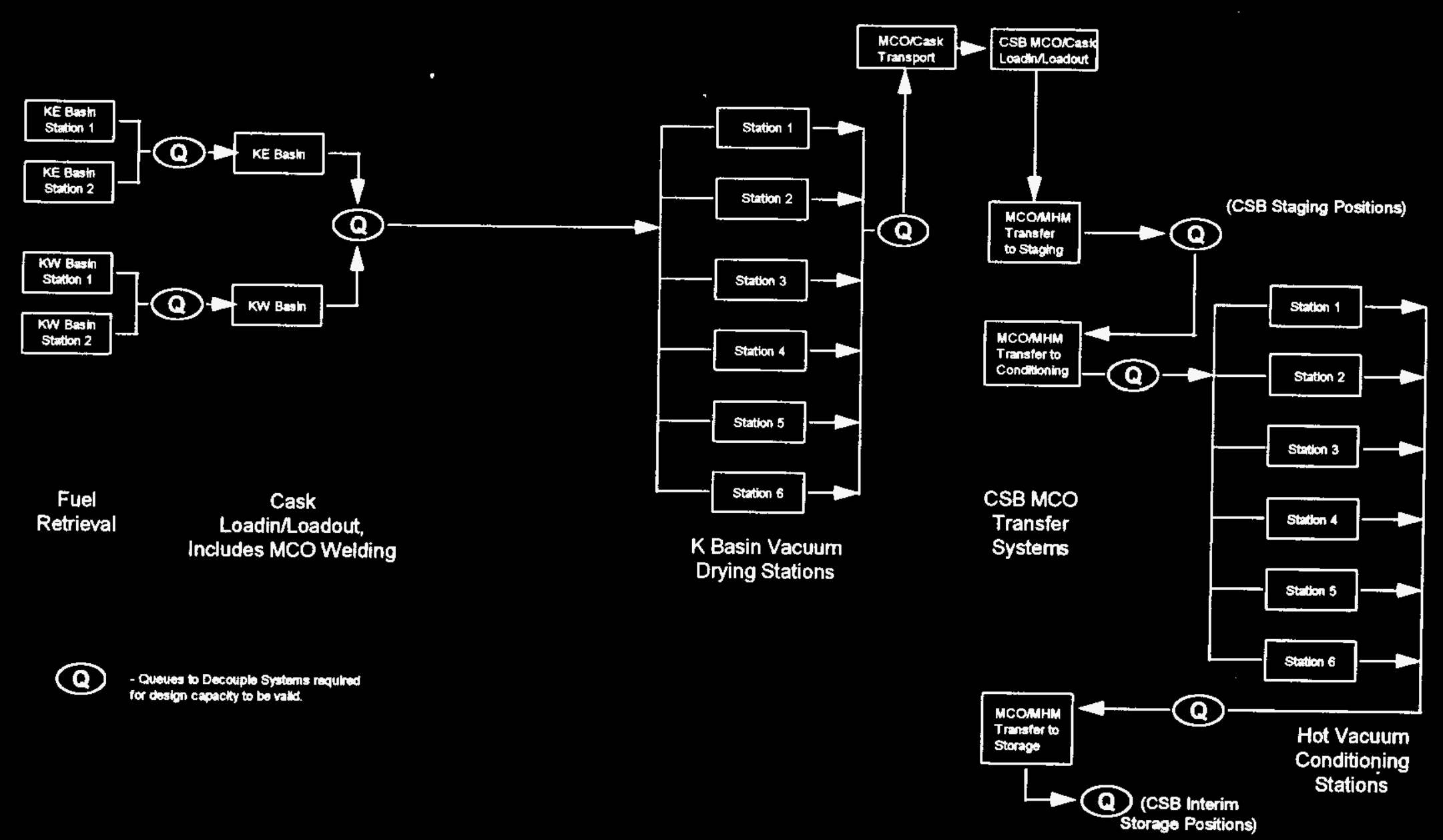


WHC-SD-SNF-TI-016, Rev. 0

Table of Contents

EXECUTIVE SUHARY ..................... i List of Tables .................... vii

List of figures .................... vii

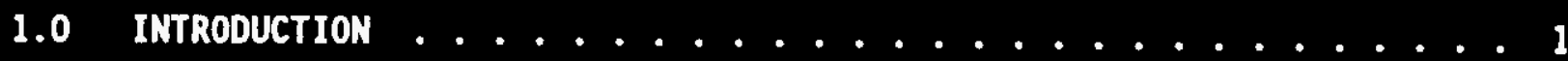

2.0 HISTORICAL PERSPECTIVE .................. 1

3.0 CAPACITY ANALYSIS BASIS ................ 3

4.0 INFLUENCE OF LEARNING CURVE PROFILES AND OPERATING PHILOSOPHY . . . 5

5.0 TOTAL OPERATING EFFICIENCY ESTIMATES FOR SPENT NUCLEAR FUEL PROJECT SYSTENS $\ldots \ldots \ldots$ 5.1 TOE Estimate Factors $\ldots \ldots$

5.2 In-Basin Activity TOE Estimates $\ldots \ldots \ldots \ldots$

5.3 Out-of-Basin Activity TOE Estimates $\ldots \ldots \ldots \ldots$

6.0 SELECTED DESIGN CAPACITY . . . . . . . . . 14

6.1 Recommended System Design Capacities ........... 17 6.1.1 Capacity of Bas in Specific systems . . . . . . . 19

$6.2 \quad 6.1 .2$ Capacity of Systems Common to Both Basins ........ 19 6.2 Impact of Configuration Changes on Required System

6.3 Importance of Queues on the Design Basis Capacity ..... 22

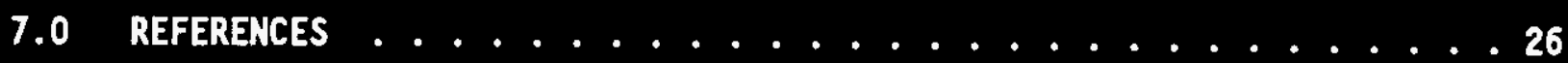


WHC-SD-SNF-TI-016, Rev. 0

List of Tables

Table ES-1. Average Capacities Required for Spent Nuclear Fuel

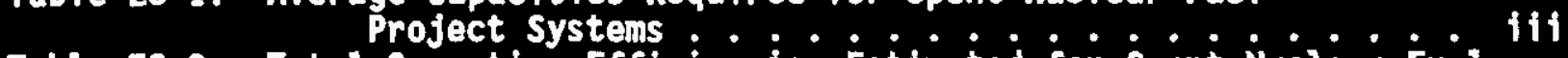

Table ES-2. Total Operating Efficiencies Estimated for Spent Nuclear Fuel

Table ES-3. Estimated Design Capacity for Spent Nuclear Fuei

Project Systens . . . . . . . . iv

Table 1. K Basin Fuei Piece Count and Estimate of Multi-Canister

Overpacks Required .............. 4

Table 2. Influence of Operation Philosophy on Average Capacity. $\ldots .8$

Table 3. Sumary of Projected System Total Operating Efficiencies . . 12

Table 4. Average Capacities Required for Spent Nuclear Fuel

Project Systems . . . . . . . . . . . 15

Table 5. Calculated Design Capacities for Basin Specific Systems $\ldots 20$

Table 6. Calculated Design Capacities for Systems Common to Both Basins - 21

Table 7. Potential Methods of Providing Queues between Process Systems . 25

\section{List of Figures}

Figure ES-1. Schematic of SNFP Systems Used for Design

Capacity Estimates . . . . . . . v v

Figure 1. Influence of Learning Curve on Sustained Capacity Required

for Basin Specific systems ....... 6

Figure 2. Influence of Learning Curve on Sustained Capacity Required

for Systems Common to Both Basins . . .... 7

Figure 3. Effect of Parallel Systems on Operating Efficiencies . . . 16

Figure 4. Schematic of SiFp Systems for Production of

Nult 1 -Canister overpacks ........... 18

Figure 5. Example of System Configuration Infiuence on

Capacity Requirements ............ 23

Figure 6. Impact of queues on Design Capacity Requirements . . . . . 24 


\section{WHC-SD-SNF-TI-016, Rev. 0 \\ DEVELOPHENT OF DESIEN BASIS CAPACITY FOR SNF PROJECT SYSTENS}

\subsection{INTRODUCTION}

A design basis capacity for the Spent Nuclear Fuel Project (SNFP) is developed by combining the desired annual processing rate with a projection of:

- the planned system operating philosophy (planned shift schedule, yielding the annual operational days available),

- anticipated influence of operation learning curve, and

- estimate of operating efficiency.

The combination of these factors identify an "instantaneous" process capacity for design purposes. Since potential operating problems reduce the number of days for production in a given year, the system design basis capacity is larger than the desired annual processing rate. The relationsh ip between the annual processing rate and the design capacity (also known as the Total Operating Efficiency, or TOE) is generally based on qualitative factors and experience with similar systems. Once established, the specified TOE is also used in an evaluation of equipment failure rates to identify the need for providing installed spare equipment such that the overall system achieves the specified TOE. However, the initial TOE for design specification is typically based on past experience.

The simple expression describing the design capacity is as follows:

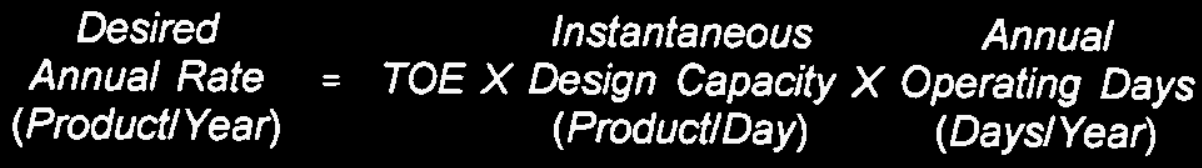

\subsection{HISTORICAL PERSPECTIVE}

Experience derived from operations at the $K$ Basins during fuel segregation activities and at the PUREX Plant provide an indication of the factors which should be considered in estimating the SNFP system TOE. Past development of the TOE relating the annual processing rate to the design capacity can be described by three factors. These factors are as follows:

1. Processing Efficiency - Fractional approach to the design throughput. The processing efficiency factor reflects the concept that design throughput projections are an idealized representation of actual operations. While operations attempt to achieve the design predictions, the reality of variations in feed materials, unanticipated instrument 


\section{WHC-SD-SNF-TI-016, Rev. 0}

problemis and other factors can limit actual activities to an approach to design rates during operation.

2. General plant Downtime - Fraction of year down for maintenance or other reason. General plant downtime represents the estimated fraction of available operating days in a year that the processing system will be unable to operate. Downt ime is generally intended to model time for equipment maintenance, such as an annual outage for extensive repairs and upgrades, or other factors which effectively prevent use of the process systems.

3. Accountability Downtime - Fraction of available operating time used to support accountability activities. This factor represents the fraction of a year where the plant could be operating, but was not producing due to completing required periodic accountability actions.

Specific documentation of operating efficiencies experienced during the $K$ Basin segregation activities has not been found. However, observations by personnel involved with these activities are summarized as follows:

- Segregation operations utilized a four shift operating philosophy, allowing operation seven days a week.

- An overall TOE for segregation activities is estimated at $60 \%$.

- Equipment repair downtime was estimated at 15 to $20 \%$, with some of the downtime attributed to the complication of performing equipment repairs under water.

- Water clarity problems further reduced the operating efficiency by approximately 7 to $10 \%$.

- Some downtime did occur to support accountability activities, but process time lost was minimal.

Prior to restart of the PUREX Plant, the Total Operating Efficiency was estimated as follows, assuming a $90 \%$ processing efficiency, general plant downtime of $20 \%$, and lost process time for accountability of $15 \%$ :

$$
\text { TOE }=0.9 \times(1-0.2) \times(1-0.15)=0.61
$$

For a mixture of $80 \%$ Mk IV and 20\% Mk 1A fuel, the PUREX Plant flowsheet predicted a design capacity of approximately $2880 \mathrm{MTU} / \mathrm{Yr}$. Therefore, the annual PUREX Plant production was initially projected to be $1750 \mathrm{MTU} / \mathrm{Yr}$ based on the original TOE estimate.

Unfortunately, the experience with PUREX Plant operations did not closely match original production predictions. PUREX operations after restart were conducted from late 1983 to mid 1989, or over about 5.5 Yrs, using a seven day per week operating schedule. In that time, 3870 MTU of fuel were processed to 
WHC-SD-SNF-TI-016, Rev. 0

yieid an average of about $700 \mathrm{MTU} / \mathrm{Yr}$. This corresponds to an overall TOE of about $25 \%$ as compared to the flowsheet design capacity. While a detailed evaluation of the TOE experience at PUREX has not been completed, the estimated plant downtime fraction is the major factor which was inaccurately predicted prior to PUREX restart, as extended periods of time were experienced where the plant was idle. Some of this downtime was for actual equipment repairs, which corresponds to the original concept for the downt ime estimate. However, much of the downtime experienced at PUREX resulted from developing responses to operational errors, the changing environmental regulatory climate which challenged the capabilities of the original plant design, the changing need for production materials causing uncertainty in whether the plant should operate or not, or was effectively down while operating because it was reworking recycled product.

It is estimated that PUREX Plant processing averaged 90\% of the original flowsheet rates when operating and did not use more than $15 \%$ of the operable time for accountability purposes. Decomposition of the TOE based on these assumptions would indicate that the plant averaged a general plant downtime of about $67 \%$.

\subsection{CAPACITY ANALYSIS BASIS}

The design capacity analysis presented in this evaluation is based on a desired annual production rate as a starting point. The capacities are presented in terms of Multi-Canister Overpacks (MCOs) prepared in a given unit of time. Therefore, the approach is based upon a desired annual production rate derived from the total number of MCOs estimated to be prepared over the project 1 ifetime and the desired period of time allowed for the project to produce these MCOS. Variation of either of the estimates used as a basis for the desired annual production rate will result in modifying the calculated design basis capacities.

The operating period used as a basis for design capacity estimates is basin dependent. All MCOs from the $\mathrm{KW}$ Basin are assumed to be produced over a 2 year period, while the operations in KE Bas in begin three months later and produce MCOS over a 1.75 year period. The operation of all systems common to both basins are assumed to be completed in a 2 year period (WHC, 1996a).

The total number of MCOS to be produced is currently estimated at 397 based on piece count information and MCO loading assumptions. This est imate is rounded to 200 MCOs from each basin for the capacity estimates. The data used to est imate the number of MCOS and loading assumptions are summarized in Table 1. An estimate range is shown in Table 1 for the MCO count which is driven by the loading assumptions. A best estimate MCO count was used in the design capacity analysis. The MCO positions required for scrap can not be estimated with certainty at this time, however, the estimate of MCO positions allocated for scrap was added to the total MCO positions estimated as if no fuel scrap is generated. This approach provides a degree of conservatism in the best estimate shown in Table 1. 
Table 1. K Basin Fuel Piece Count and Estimate of Multi-Canister Overpacks Required

\begin{tabular}{|c|c|c|c|c|c|c|c|c|c|c|}
\hline \multirow{3}{*}{$\begin{array}{l}\text { Basing } \\
\text { Fuel Type }\end{array}$} & \multicolumn{3}{|c|}{ Fuel Piece count } & \multirow{3}{*}{ Canisters } & \multirow{2}{*}{\multicolumn{2}{|c|}{ Estimated Minimum }} & \multirow{2}{*}{\multicolumn{2}{|c|}{ Estimated Maximum }} & \multirow{2}{*}{\multicolumn{2}{|c|}{$\begin{array}{l}\text { Estinated for } \\
\text { Design Basis }\end{array}$}} \\
\hline & \multirow{2}{*}{ Assembl ies } & \multirow{2}{*}{$\begin{array}{c}\text { Lone } \\
\text { Outers } \\
\end{array}$} & \multirow{2}{*}{$\begin{array}{l}\text { Lone } \\
\text { Inners }\end{array}$} & & & & & & & \\
\hline & & & & & Baskets & MCO & Baskets & MCO & Baskets & $\mathrm{MCO}$ \\
\hline $\begin{array}{l}\text { KE Basin: } \\
\text { MK IV N Fuel } \\
\text { SPR } \\
\text { Scrapholders } \\
\text { KE Basin Total }\end{array}$ & $\begin{array}{r}50,439 \\
138\end{array}$ & 243 & 253 & $\begin{array}{r}3,668 \\
4 \\
3,672 \\
\end{array}$ & $\begin{array}{r}939 \\
\text { See Note } 1 \\
48 \\
987\end{array}$ & $\begin{array}{r}188 \\
\$ \\
8 \\
196 \\
\end{array}$ & $\begin{array}{r}1,062 \\
4 \\
48 \\
1,110 \\
\end{array}$ & $\begin{array}{r}213 \\
8 \\
8 \\
221 \\
\end{array}$ & $\begin{array}{r}965 \\
4 \\
48 \\
1,013 \\
\end{array}$ & $\begin{array}{r}193 \\
8 \\
201 \\
\end{array}$ \\
\hline $\begin{array}{l}\text { KW Basin: } \\
\text { Mk 1A N Fuel }\end{array}$ & 38,614 & 28 & 26 & 2,780 & 806 & 135 & 921 & 154 & 834 & 139 \\
\hline $\begin{array}{l}\text { Wk IV N Fuel } \\
\text { W Fuel from PuREx }\end{array}$ & 14,243 & $\begin{array}{l}85 \\
47\end{array}$ & 90 & 1,037 & 267 & 54 & 302 & 61 & 275 & 55 \\
\hline SPR from PUREX & $\begin{array}{r}47 \\
784\end{array}$ & & & $20^{2}$ & 9 & 1 & 9 & 1 & 9 & 1 \\
\hline $\begin{array}{l}\text { Scrapholders } \\
\text { KM Basin Total }\end{array}$ & & & & 3,841 & $\begin{array}{r}6 \\
1,088 \\
\end{array}$ & $\begin{array}{r}1 \\
191 \\
\end{array}$ & $\begin{array}{r}6 \\
1,238 \\
\end{array}$ & $\begin{array}{r}1 \\
217\end{array}$ & $\begin{array}{r}6 \\
1,124\end{array}$ & $\begin{array}{r}1 \\
196\end{array}$ \\
\hline$K$ Basin Total & & & & 7,513 & 2,075 & 387 & 2,348 & 438 & 2,137 & 397 \\
\hline
\end{tabular}

Notes:

1. Estimated Minimum assunes maximum Loading of basket positions. Lone inners and outers reassembled to minimize basket positions used.

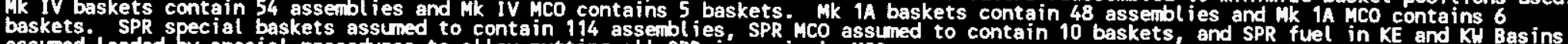
assuned loaded by special procedures to allow putting all SPR in a single MCO.

2. Estimated Maximm assumes that a close packed loading schene for baskets is not feasible such that Hk iv fuel basket loading is contains 5 baskets and hik 14 MCO contains 6 baskets. SPR special baskets, MCO and loading procedure sane in in mete (1). 3. Estimate for Design Basis assumes fixed number of canisters loaded into each mco to sinplify accountability. Loading is estimated to be equivatent to and at least 8 empty positions per Mk $1 \mathrm{~A}$ MCO. SPR special baskets, MCO and loading procedure same as in note $(1\}$.

4. Scrapholder MCO estimate is an allocation at this time.

5. Piece count and canister count data is as reported from CoLDMAC database as of January 1996 (WHC, $1996 \mathrm{~b}$ ).

6. W Fuel from PUREX combined with Mk IV for estimate of MCOS in KW Basin assuming elements can not be combined to form assemblies. 
WHC-SD-SNF-TI-016, Rev. 0

\subsection{INFLUENCE OF LEARNING CURVE PROFILES AND OPERATING PHILOSOPHY}

Most new systems undergo a learning curve which influences production while operators learn how to effectively utilize the process equipment. Frequently, this startup period can be neglected during selection of a design capacity when operations are planned to continue for long time periods. Since the SNFP processing is desired to be completed over a relatively short period, initial operations at a reduced rate can impact design capacity selection. Figure 1 indicates the influence a learning curve can have on the sustained average capacity (no TOE included) required to produce $200 \mathrm{MCOs}$ from each bas in over the projected operating time. Figure 2 indicates similar relationships for systems common to both basins based on handing 400 MCOs over the operating period. These common systems are of two types. The first type has a capacity requirement as indicated in Figure 2(a) where the common systems must support a composite of the individual basin capacities. This represents systems including Cold Vacuum Drying, Cask Transportation to the CSB, and cask loadin/loadout at the CSB for placement of MCOS in staging. The staging capacity at the CSB allows systems common to both basins after staging to be based on reduced capacity requirements, as shown in Figure 2(b).

For the simple model presented in Figures 1 and 2, the effectiveness of operation is assumed to increase linearly to a sustained production level. The linear increase in production is duplicated as a production decrease to one-half the sustained level in the last three months of operation to model the situation where fuel requiring more time consuming processing is left to the end of the operating period. This simple comparison indicates that the sustained overall average capacity required to produce 200 MCOs from KW Basin increases from $100 \mathrm{MCO} / \mathrm{Yr}$ with no learning curve assumed, to the equivalent of $110 \mathrm{MCO} / \mathrm{Yr}$ and $119 \mathrm{MCO} / \mathrm{Yr}$ for learning curve profiles of 3 months and 6 months, respectively. Similar variations in the sustained capacity with respect to the assumed learning curve are observed for KE Bas in and systems common to both basins.

The selected operating philosophy influences the system design capacity by specifying the number of days available for operating the process in a year. A three shift operating philosophy allows process operation 5 days/week, while a five shift operating philosophy (four operating, plus one training) allows process operations 7 days/week. These alternative operating philosophies simplify to providing either 250 or 365 available days per year (av day/Yr) as a basis for the design capacity.

Table 2 provides a quantitative comparison of the average capacity required during the available operating days for various learning curve and operating philosophy assumptions. These average capacity estimates do not include the influence of operating efficiency and, therefore, reflect the production rate which must be achieved on average to complete the project in the desired operating period. 
WHC-SD-SNF-TI-016, Rev. 0

Figure 1. Influence of Learning Curve on Sustained Capacity Required for Basin Specific Systems

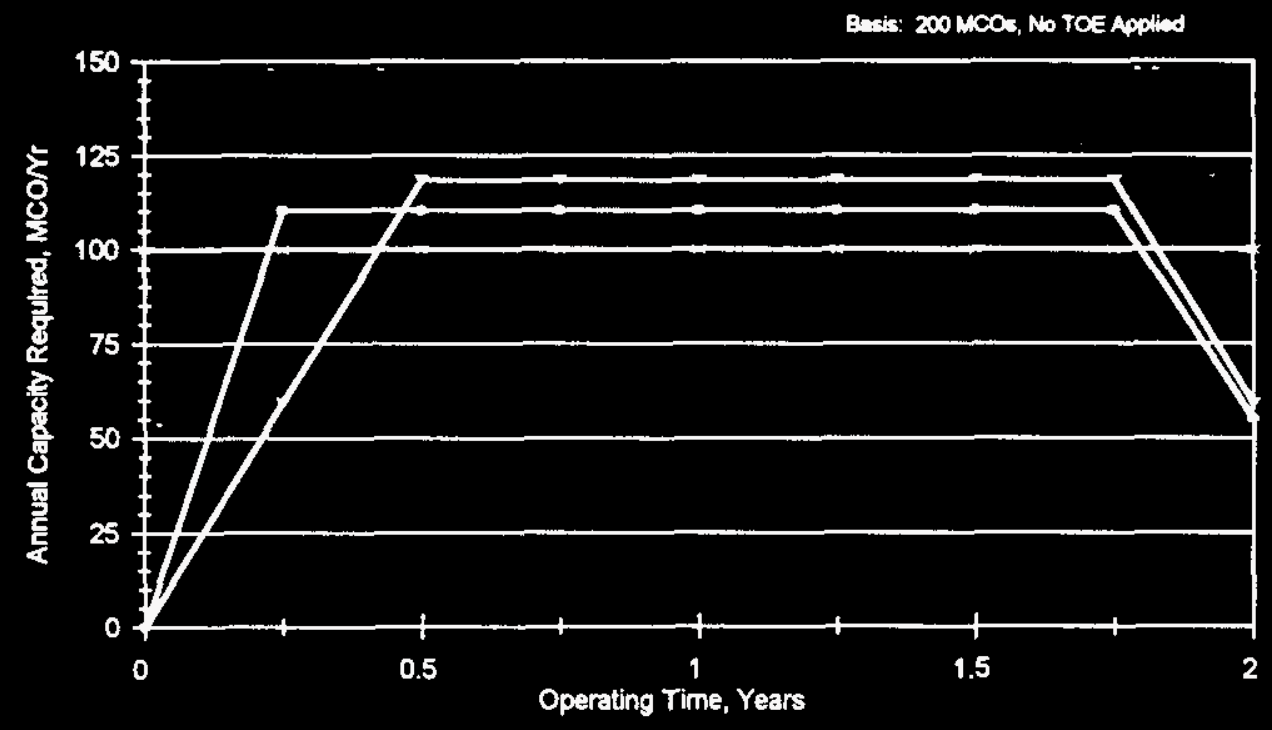

Figure 1(a). KW Basin Systems

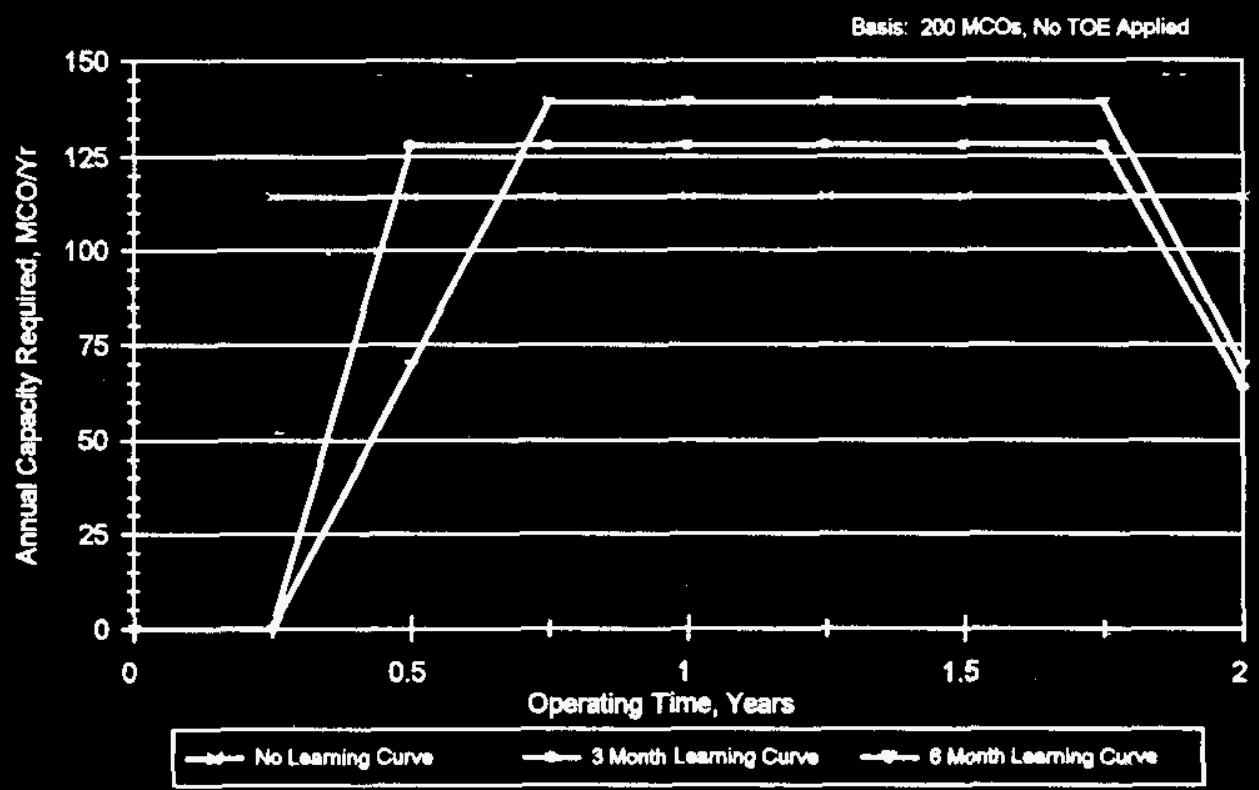

Figure 1(b). KE Basin Systems 
WHC-SD-SNF-TI-016, Rev. 0

Figure 2. Influence of Learning Curve on Sustained Capacity Required for Systems Common to Both Basins

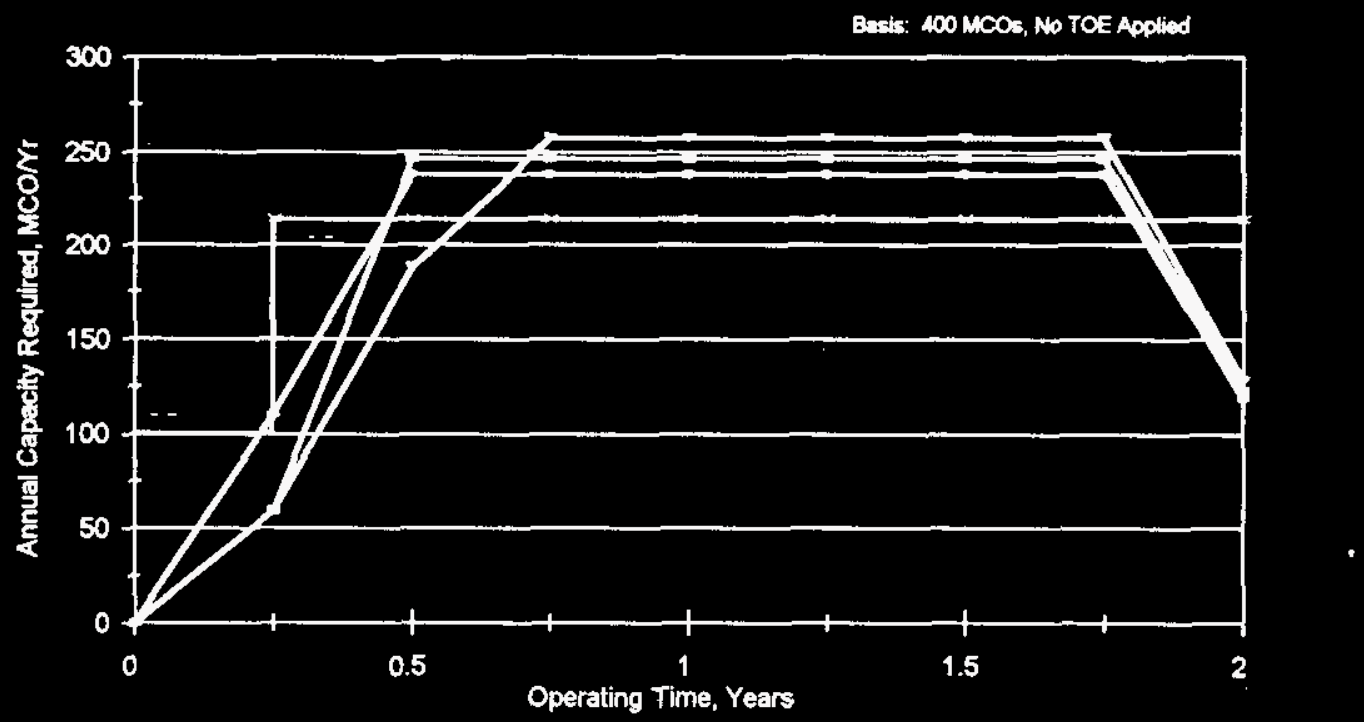

Figure 2(a). Systems Common to Both Basins through CSB Staging

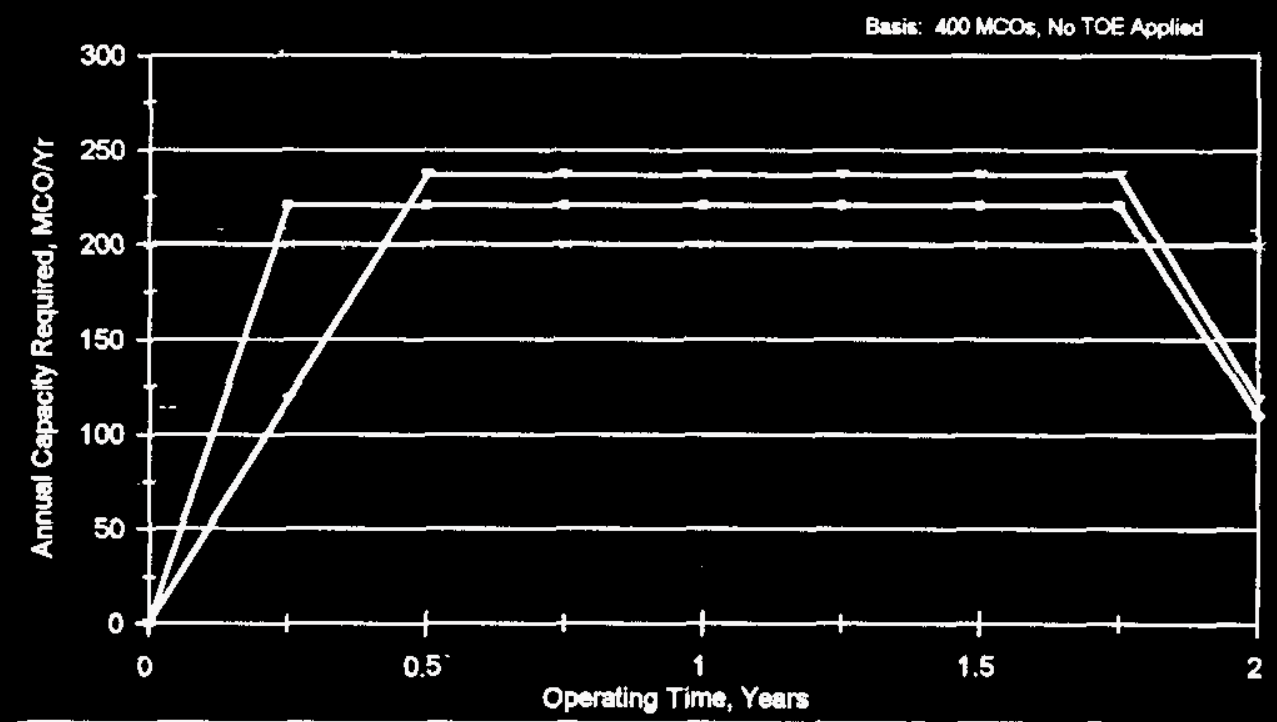

- No Leaming Curve $\quad-3$ Month Leaming Curv $\rightarrow 6$ Month Laaming Curve $\rightarrow-6$ Month KW/3 Month KE

Figure 2(b). Systems Common to Both Basins after CSB Staging 
WHC-SD-SNF-TI-016, Rev. 0

Table 2. Influence of Operation Philosophy on Average Capacity (Excludes effect of Operating Efficiency)

\begin{tabular}{|c|c|c|c|c|}
\hline & \multirow{2}{*}{$\begin{array}{l}\text { Assuned } \\
\text { Learning } \\
\text { Curve }\end{array}$} & \multirow{2}{*}{$\begin{array}{l}\text { Sustained } \\
\text { Capacity } \\
\text { (Mco/rr\} }\end{array}$} & \multicolumn{2}{|c|}{ Average Capacity (MCO/av day) } \\
\hline & & & 5 doy/week operation & 7 doy/week Operation \\
\hline KM Basin Systems & $\begin{array}{l}\text { Mone } \\
3 \text { Wonth } \\
6 \text { Honth }\end{array}$ & $\begin{array}{l}100 \\
110 \\
119\end{array}$ & $\begin{array}{l}0.40 \\
0.44 \\
0.48\end{array}$ & $\begin{array}{l}0.27 \\
0.50 \\
0.35\end{array}$ \\
\hline KE Basin Systens & 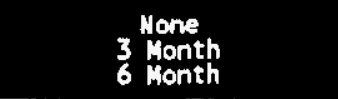 & $\begin{array}{l}114 \\
128 \\
139\end{array}$ & $\begin{array}{l}0.46 \\
0.51 \\
0.56\end{array}$ & $\begin{array}{l}0.31 \\
0.35 \\
0.38\end{array}$ \\
\hline $\begin{array}{l}\text { Systens Common to } \\
\text { Both Basins through } \\
\text { CSB staging }\end{array}$ & 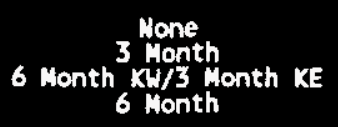 & $\begin{array}{l}214 \\
248 \\
247 \\
258\end{array}$ & $\begin{array}{l}0.86 \\
0.95 \\
0.99 \\
1.03\end{array}$ & $\begin{array}{l}0.59 \\
0.55 \\
0.68 \\
0.71\end{array}$ \\
\hline $\begin{array}{l}\text { Systems Common to } \\
\text { Both Basins after } \\
\text { CSB Staging }\end{array}$ & $\begin{array}{l}3 \text { Mone } \\
3 \text { Month } \\
6 \text { Month }\end{array}$ & $\frac{200}{221}$ & $\begin{array}{l}0.80 \\
0.88 \\
0.95\end{array}$ & $\begin{array}{l}0.55 \\
0.60 \\
0.65\end{array}$ \\
\hline
\end{tabular}

Note: 5 day/week Operation = 250 available days (av day)/Yr, 7 day/week Operation $=365$ av day/Yr

It should be noted that past operating experience with a three shift operating schedule at the Plutonium Finishing Plant (PFP) indicates a potential for observing fewer than five effective operating days per week with this operating philosophy. At the PFP, it was not unusual to use the first operating day of the week restarting operations and the last operating day of the week shutting down operations. This 1 imited effective operation to three days per week. However, PFP operated continuous flow process systems which required establishing steady state conditions for effective processing, while the SNF Project processes are basically a sequence of batch activities.

Some weekly start-up/shut-down inefficiency may be experienced with the three shift operating philosophy for SNF Project activities, although it is not expected to be as significant as that experienced by the PFP due to the difference in batch versus continuous processing. This operating inefficiency could occur if batches prepared for introduction into drying or conditioning systems, with long cycle times, periodically fall behind schedule such that a complete cycle can not be finished prior to the end of the work week. If this event occurs, a batch would either be held for starting the next week, or started and completed on the weekend using overtime operator support. The first case would decrease the operating efficiency of the system, while the second case would increase annual operating costs. No allowance was included in this design capacity estimate to specifically address this type of operating inefficiency and it is expected that decisions on how to accommodate batch timing problems would be made on a case-by-case basis after operations have been initiated. 


\section{WHC-SD-SNF-TI-016, Rev. 0 \\ 5.0 TOTAL OPERATING EFFICIENCY ESTIMATES FOR SPENT NUCLEAR FUEL PROJECT SYSTEMS}

Application of past experience to development of a Total Operating Efficiency (TOE) for the Spent Fuel Project should be done with a degree of caution. In its simplest form, it might be assumed to directly utilize the TOE estimate of $60 \%$ estimated for past segregation activities at the basin. Similarly, the PUREX Plant experience of $25 \%$ operating efficiency could be directly used as the basis for a Spent Fuel Project design TOE. The PUREX Plant TOE experience is likely too conservative for the SNF Project, assuming modern designs are implemented and a continued commitment for removal of fuel from the basins throughout the operating period. Past bas in experience may not adequately reflect the difference in complexity of fuel segregation activities as compared to the planned SNF Project. Therefore, the following estimate was developed based on an evaluation of factors which could effectively result in lost production.

The SNF Project was divided into major systems for removal of fuel from the basins. The systems were then grouped into In-Bas in and Out-of-Bas in activities (as defined in Sections 5.2 and 5.3), as well as considering the type of process steps performed, for application of the TOE factors.

\subsection{TOE Estimate Factors}

The TOE estimate is divided into five factors described below as a basis for the analysis. These factors are identical to the three factors described in Section 1.0, with general plant downtime sub-divided into three elements (product rework, work environment, and equipment downtime) derived from reported experience from $K$ Bas in segregation activities. Estimates for each factor are discussed below.

1. Processing Efficiency - The efficiency factor modeling approach to ideal flowsheet activities is continued to be estimated at $90 \%$. This is considered a realistic, but not conservative, goal for plant operations, recognizing that the spent fuel path forward is a sequence of series and parallel batch operations similar to that encountered in the PUREX Plant headend. Experience with this type of activity indicates that operational vigilance will be required to approach capacities predicted by theoretical time cycle analyses. The processing efficiency factor is assumed applicable to both In-Basin and out-of-Basin activities.

2. Product Rework - The potential need for rework exists in some SNF Project activities and may take the form of recycling elements through cleaning steps during fuel retrieval, reworking welds that do not pass inspection, or redrying loaded MCO's that do not comply with product criteria. An effective lost production factor of $10 \%$ is allocated for material rework. The product rework efficiency factor becomes $90 \%$ and is assumed applicable to both In-Basin and Out-of Basin activities containing processing steps with a potential for requiring rework.

3. Work Environment - The work environment factor was included to address 


$$
\text { WHC-SD-SNF-TI-016, Rev. } 0
$$

inefficiencies experienced within the $K$ Basin fuel storage pools during past fuel segregation. Operator dress requirements reduce the operating time available each shift. It is estimated that dress requirements will constrain the effective time an operator can perform work to approximately six hours in an eight hour shift. Therefore, an element of the work environment efficiency factor was assumed to be $75 \%$, which is allocated to systems likely to include manual intensive activities, such as fuel retrieval.

Other system activities are projected to result in operator dress inefficiencies, however, the process design is likely to require periodic manual support. The fuel drying systems are an example of this type of system, where manual operations are required to set up and disconnect a drying station which is then operated continuously for an extended time period. The operator dress efficiency factor for this periodic manual type of activity was assumed to be $80 \%$.

Achieving the assumed operator dress factors may require some innovative personnel planning to achieve. Current $K$ Bas in operations are reported to achieve approximately four hours of effective work per shift. This is similar to the experience reported by BNFL for operator effectiveness which consists of four to five hours per shift in protective clothing and six hours without protective clothing.

In addition to operator dress inefficiencies, fuel segregation experienced downtime due to water clarity problems which prevented fuel movement. While the SNF Project activities are implementing systems to address this problem (which should be limited to the KE Basin), an assumption is included in the work environment factor that $10 \%$ of the operating time is lost due to water clarity problems. This factor is assumed to be sufficient to also accommodate the reliability of water treatment systems (currently expected to use a reliability of $95 \%$ as a design goal) which may be required to be in operation for fuel, sludge, or debris removal systems to operate. The factor becomes a $90 \%$ efficiency which is applied only to In-Basin activities with the potential to be delayed by loss of vision to perform work due to sludge plumes or water treatment system downtime.

4. Equipment Downtime - The equipment downtime factor is difficult to predict and apply to the SNFP situation. Elements of the PUREX Plant downt ime experience would not be expected to be applicable to the SNFP. These factors include operational delays to reassess the need for production and changes in the regulatory climate.

The overall production period for systems in the SNF Project is planned for about 2 Yrs. This short operational period would be expected to experience few outages for equipment repairs and 1ikely would not require any general maintenance outage to be scheduled, assuming that the systems are primarily supported by new equipment in a relatively benign chemical environment. 
Downtime as a response to operational errors is difficult to predict into the future, particularly for a system design with no operational history. It is recommended that consideration of downtime as a response to operational errors be eliminated as a factor in development of a TOE for design purposes. Errors could become a factor in the actual production rate experienced, but management systems are put in place to minimize operational errors and it is considered inappropriate to include planning on operational errors to occur as a supplement to the downt ime estimate.

Lacking a calculated reliability of the planned system designs, an equipment downtime efficiency factor of $80 \%$ was generally assumed. This value is similar to that experienced by $K$ Basin fuel segregation activities and is applied to both In-Bas in and Out-of-Bas in SNFP activities. Cask loadin/loadout at the CSB was considered an exception to this assumption as the downtime is estimated to be dominated by a new crane for cask movements. An operating efficiency for equipment in the CSB cask loadin/loadout system was estimated at 95\%.

5. Accountability Downtime - The detailed requirements for accountability have not been established for the SNFP. However, activities associated with the annual inventory at the $K$ Basins, Conditioning Facility and Canister Storage Building will likely reflect the time required to inventory the present $K$ Basins. This results in an annual shut down estimated at three to five days. The shut down covers stopping work in all SNFP facilities on the same day, updating documentation describing the location of all materials, and inspecting material to verify the actual location is consistent with records.

An allocation for the SNFP TOE estimate is based on reserving 10 days for accountability activities within the $2 \mathrm{Yr}$ operating period. Accountability inventories are performed at the same time across the site each year and SNFP operations must accommodate the dictated schedule. This concept provides an efficiency factor of $99 \%$ to address accountability actions and is applied to both In-Basin and out-of-Basin activities.

Using the factors described above in combinations specific to the activities in each SNFP system, yields the TOE estimates included in the design basis capacity estimates.

\subsection{In-Basin Activity TOE Estimates}

In-Basin activities include those systems which perform material movements within the $K$ Basin fuel storage pool (i.e., underwater). These systems of the SNFP include Debris Removal, Sludge Remova1, Fuel Retrieval (fuel canister retrieval through loading fuel baskets into a MCO), and Cask Loadin/Loadout (empty MCO/cask into and loaded MCO/Cask removal from the bas in loadout pit). Alternatives currently under consideration for location of the MCO shield plug welding system can impact the factors included in the Cask Loadin/Loadout operating efficiency. Total operating efficiency estimates for the In-Basin 
Table 3. Summary of Projected System Total Operating Efficiencies

\begin{tabular}{|c|c|c|c|c|c|c|c|}
\hline \multirow{3}{*}{ System } & \multicolumn{6}{|c|}{ Total Operating Efficiency Elements } & \multirow{3}{*}{$\begin{array}{c}\text { Single System } \\
\text { Total Operating } \\
\text { Efficiency }\end{array}$} \\
\hline & \multirow{2}{*}{$\begin{array}{l}\text { Process } \\
\text { Efficiency }\end{array}$} & \multirow[t]{2}{*}{ Rework } & \multicolumn{2}{|c|}{ Work Enviromment } & \multirow{2}{*}{$\begin{array}{l}\text { Equipment } \\
\text { Downt ime }\end{array}$} & \multirow[t]{2}{*}{ Accountability } & \\
\hline & & & $\begin{array}{l}\text { Operator } \\
\text { Dress }\end{array}$ & $\begin{array}{c}\text { Water } \\
\text { clarity/ } \\
\text { Treatment* }\end{array}$ & & & \\
\hline $\begin{array}{l}\text { IN-BASIN ACTIVITIES: } \\
\text { Debris Removal }\end{array}$ & 0.9 & N/A & 0.75 & 0.9 & 0.8 & 0.99 & 0.48 \\
\hline Sludge Removal & 0.9 & N/A & 0.75 & 0.9 & 0.8 & 0.99 & 0.48 \\
\hline Fuel Retrieval & 0.9 & 0.9 & 0.75 & 0.9 & 0.8 & 0.99 & 0.43 \\
\hline $\begin{array}{l}\text { Cask Loadin/Loadout, } \\
\text { including Mco Helding }\end{array}$ & 0.9 & 0.9 & 0.75 & N/A & 0.8 & 0.99 & 0.48 \\
\hline $\begin{array}{l}\text { Cask Loadin/Loadout } \\
\text { (if excludes HCO welding) }\end{array}$ & 0.9 & $N / A$ & 0.75 & N/A & 0.8 & 0.99 & 0.54 \\
\hline $\begin{array}{l}\text { OUT-af-BasIN ACtIvItIES: } \\
\text { Mco Melding } \\
\text { (if co-located with } \\
\text { Vaculm Drying) }\end{array}$ & 0.9 & 0.9 & 0.75 & N/A & 0.8 & 0.99 & 0.48 \\
\hline $\begin{array}{c}\text { K Basin SWF } \\
\text { Vacuun Drying }\end{array}$ & 0.9 & 0.9 & 0.8 & $\mathbf{H} / \mathbf{A}$ & 0.8 & 0.99 & 0.51 \\
\hline Cask/Transport** & & & & & & & 1.00 \\
\hline $\begin{array}{l}\text { Canister Storage Building } \\
\text { Cask Loadin/Loadout }\end{array}$ & 0.9 & $\mathrm{~N} / \mathrm{A}$ & 0.8 & W/A & 0.95 & 0.99 & 0.68 \\
\hline $\begin{array}{l}\text { Canister Storage Building } \\
\text { Mco Transfers in }\end{array}$ & 0.9 & $W / A$ & N/A & N/A & 0.8 & 0.99 & 0.71 \\
\hline $\begin{array}{l}\text { Hot Vacum } \\
\text { conditioning }\end{array}$ & 0.9 & 0.9 & 0.8 & W/A & 0.8 & 0.99 & 0.51 \\
\hline
\end{tabular}

Notes: $N / A=$ Not Applicable

$*$ = Assumed to include reliability of Hater Treatment systems.

** = Cask transport, once loaded or unloaded, was assuned to be a high reliability system. 
WHC-SD-SNF-TI-016, Rev. 0

activities are estimated as shown in Table 3 using a combination of factors from Section 5.1. The TOE for each activity includes the process efficiency, equipment downt ime, operator dress and accountability factors. The water clarity/treatment factor is only included in each of the TOE est imates for Debris Removal, Sludge Removal, and Fuel Retrieval. This factor is excluded from the Cask Loadin/Loadout estimates as it was assumed that visibility problems with accessing fuel in baskets will be alleviated once the fuel is cleaned by Fuel Retrieval.

The rework factor has been included for the Cask Loadin/Loadout system when combined with. MCO Welding and for Fuel Retrieval. If MCO Welding is an integral part of the Cask Loadin/Loadout cycle, welding of the MCO lid and weld integrity checks produces a potential for identifying the need for reworking some welds. The Fuel Retrieval system is assumed to contain a potential for rework as part of the fuel cleaning step.

\subsection{Out-of-Basin Activity TOE Estimates}

Out-of-Basin activities include those systems which perform material movements outside the $K$ Bas in fuel storage pool. These systems include MCO Welding (if decoupled from the Cask Loadin/Loadout system), Vacuum Drying, Staging and Storage in the Canister Storage Building, and Hot Vacuum Conditioning. Total operating efficiency estimates for Out-of-Basin activities are also indicated in Table 3 . Process efficiency, work environment, equipment downt ime, and accountability downtime are included as factors in each of these system TOE estimates. In addition, MCO Welding, Vacuum Drying and Hot Vacuum Conditioning include process steps with the potential for identifying the need for rework and the rework factor identified in the discussion above was included to the TOE estimate for these systems.

The TOE estimate factors were not applied to the cask/transport system. It was assumed that this system would be provided with sufficient reliability to preclude impacting the TOE of other systems. 
WHC-SD-SNF-TI-016, Rev. 0

\subsection{SELECTED DESIEN CAPACITY}

The previous sections develop the basis for factors used for the design basis capacity of SNFP systems. These factors are summarized as:

- The desired operating period is defined by the schedule in WHC, 1996a. This includes a 2 year operating period for KW Basin systems, a 1.75 year operating period for KE Basins systems which begin operating three months after the KW Basins systems, and systems common to both basins operated for 2 years.

- A total of 400 MCOs will be produced during the operating period (200 from each basin).

- A learning curve of 6 months is assumed for KN Basin systems and 3 months for KE Basins systems to allow for inefficiencies during startup. This generates a learning curve allowance spread over six months for systems common to both basins. Sustained capacities are obtained from Figures 1 and 2. The required sustained capacity is dependent on whether a system supports a specific basin, is common to both basins through CSB staging, or is common to both basins after CSB staging. The sustained capacity requirements are summarized by system in Table 4.

- The operating philosophy assumed is a combination of 3 shift and 5 shift operations based on the assumptions contained in the current version of the project staffing plan (WHC, 1996C). The operating philosophy assumption is presented for each system in Table 4.

The operating efficiency is system dependent and summarized in Table 3.

The factors in Table 3 provide estimates of the operating efficiency of a single system. However, the configuration of systems will influence the design capacity required. Operation of multiple parallel stations will improve the overall TOE of a system, while a series configuration reduces the TOE. The following equations for a system containing two processes indicates the different relationships used to estimate system operating efficiencies for alternative system configurations (Rudd 1968).

Series: $\quad \mathrm{TOE}_{\text {sys }}=\mathrm{TOE}_{1} \times \mathrm{TOE}_{2}$

Paralle]: $\quad \mathrm{TOE}_{\mathrm{sys}}=1-\left[\left(1-\mathrm{TOE}_{1}\right) \times\left(1-\mathrm{TOE}_{2}\right)\right]$

Figure 3 illustrates the impact of two to six parallel stations on the overall system operating efficiency, assuming elements of the parallel system have identical TOE. 
WHC-SD-SNF-TI-016, Rev. 0

Table 4. Average Capacities Required for Spent Nuclear Fuel Project Systems

\begin{tabular}{|c|c|c|c|c|c|}
\hline \multirow[t]{2}{*}{ Systems } & \multirow{2}{*}{$\begin{array}{l}\text { Susteined } \\
\text { Capacity } \\
\text { (Aco/Yr) }\end{array}$} & \multicolumn{2}{|c|}{ Operating Philosophyt* } & \multirow{2}{*}{$\begin{array}{l}\text { Required } \\
\text { Average } \\
\text { Capacity } \\
\text { (uco/av day) }\end{array}$} & \multirow{2}{*}{$\begin{array}{l}\text { Average } \\
\text { Capacity, } \\
\text { Rounded } \\
\text { (mCo/av day) }\end{array}$} \\
\hline & & $\begin{array}{c}\text { Operat ing Days } \\
\text { per Week }\end{array}$ & av day/Yr & & \\
\hline $\begin{array}{l}\text { KU Basin Systens: } \\
\text { - Ku Fuel Retrieval } \\
\text { - Ku Cask Loodin/Losdout }\end{array}$ & $\begin{array}{l}119 \\
119\end{array}$ & $\begin{array}{l}5 \\
5\end{array}$ & $\frac{250}{250}$ & $\begin{array}{l}0.48 \\
0.48\end{array}$ & $\begin{array}{l}0.5 \\
0.5\end{array}$ \\
\hline $\begin{array}{l}\text { KE Basín Systens: } \\
\text { - KE Fuel Retrieval } \\
\text { - KE Cask Loadin/Lodout }\end{array}$ & $\frac{128}{128}$ & $\begin{array}{l}5 \\
5\end{array}$ & 250 & $\begin{array}{l}0.51 \\
0.51\end{array}$ & $\begin{array}{l}0.5 \\
0.5\end{array}$ \\
\hline $\begin{array}{l}\text { Systens Common to Both Basins } \\
\text { through CSB Staging: } \\
\text { - Cold Vacuun Drying } \\
\text { - Cask Transport } \\
\text { - CSB MCO/Cask Loadin/Loadout } \\
\text { - CSB/MHM Transfer to Staging }\end{array}$ & $\begin{array}{l}247 \\
247 \\
247 \\
247\end{array}$ & $\begin{array}{c}7+* t \\
5 \\
5 \\
5\end{array}$ & $\begin{array}{l}250 \\
250 \\
250 \\
250\end{array}$ & $\begin{array}{l}0.99 \\
0.99 \\
0.99 \\
0.99\end{array}$ & $\begin{array}{l}1.0 \\
1.0 \\
1.0 \\
1.0\end{array}$ \\
\hline $\begin{array}{l}\text { Systems Common to Both Basins } \\
\text { after csB staging: } \\
\text { - csB/MHM to Conditioning } \\
\text { - CSB/MH to Storage } \\
\text { - Hot Vacum Conditioning }\end{array}$ & $\begin{array}{l}237 \\
237 \\
237\end{array}$ & $\begin{array}{l}7 \\
7 \\
7\end{array}$ & $\begin{array}{l}365 \\
365 \\
365\end{array}$ & $\begin{array}{l}0.65 \\
0.65 \\
0.65\end{array}$ & $\begin{array}{l}0.65 \\
0.65 \\
0.65\end{array}$ \\
\hline
\end{tabular}

Note: $\quad$ * - Sustained capacity from figures 1 and 2 for six month KH Bas in learning curve, three month $k E$ Basin learning curve, and six month learning curve for systems cantion to both basins after CSB staging.

** - Operating philosophy consistent with WHC, 1996c. av day = available days

*** - The current staffing plan is based on 7 day per week operation for cold vacum drying to support multi-day cycle times, but effective days of operation each year assumed limited to 250
days/year due to feed production constraints by basin systems. 
WHC-SD-SNF-TI-016, Rev. 0

Figure 3. Effect of Parallel Systems on Operating Efficiencies

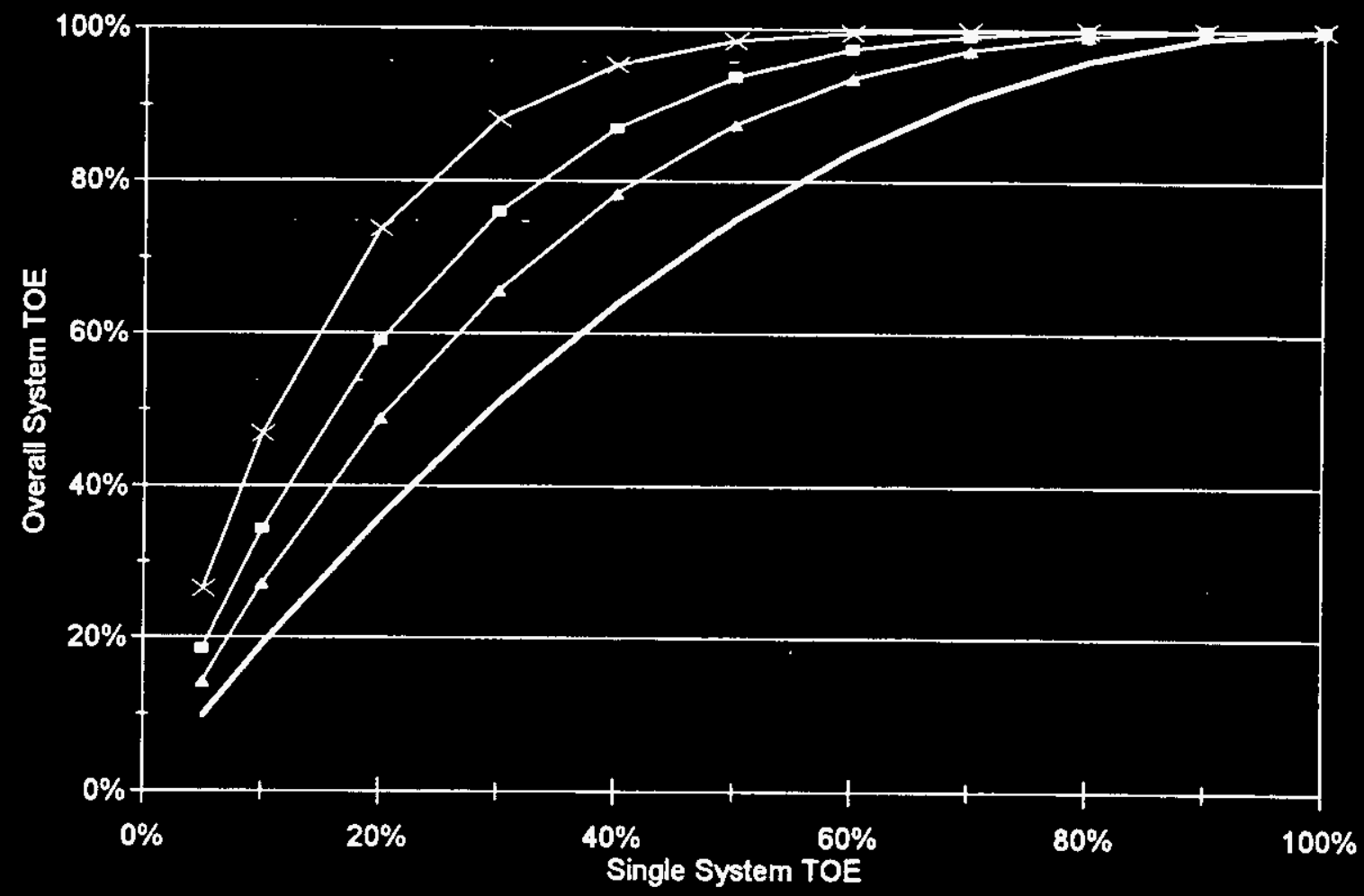

2 Parallel Systems $\rightarrow-3$ Paraliel Systems $\rightarrow-4$ Parallel Systems $-\leftarrow-6$ Parallel Systems 
WHC-SO-SNF-TI-016, Rev. 0

Figure 4 presents a simplified schematic of the current concept for major SNFP process systems producing a MCO, emphasizing the systems and stations

projected to be in series and parallel configurations. The schematic is based on the configuration identified by WHC, 1995 and includes the projection of parallel stations assumed in WHC, 1996c. This configuration is expected to change as the project designs are developed in detai1. As indicated on Figure 4, the design capacities estimated in this study are based on the assumption that queues are included in the design that effectively isolate each major system from one another to prevent downtime in one system from impacting operation of the remaining systems. These queues are important to the design capacity calculation as they eliminate the need to further reduce systen TOEs by the series equation described above.

Fuel retrieval and basin cask loadin/loadout systems are specific to an individual basin. Two fuel retrieval stations in parallel, feeding a single cask loadin/loadout system, are assumed to be provided in each basin. Welding the MCO shield plug in place is currently included in the cask loadin/loadout cycle, however, studies are in progress which may modify the MCO welding system location.

MCOs from the basin cask loadin/loadout system are transferred to the $K$ Basin Vacuum Drying system. This system is currently projected to contain approximately six parallel drying stations capable of operating independently from one another. Therefore, operating efficiencies for this system are adjusted using the parallel system equation described above.

MCOs are transferred from the vacuum drying system to the Canister Storage Building (CSB) where they enter via a cask loadin/loadout system. After receipt, the MCOs are transferred in a MCO Handling Machine (MHM) to a CSB vault tube for staging. The same MHM removes the MCO from staging and transfers it to the conditioning systems.

The Hot Vacuum Conditioning system is currently projected to contain approximately six parallel conditioning stations capable of operating independently from one another. Therefore, operat ing efficiencies for this system are adjusted using the parallel system equation described above. After conditioning, the MHM removes the MCO and transfers it to a CSB vault tube for storage.

\subsection{Recomnended System Design Capacities}

At this point in the SNFP development, only an average capacity for systems as indicated in Table 4 can be recommended as a common requirement for SifP process systems. Due to the configuration dependence of the instantaneous design capacity, design capacities can only be developed based on the current concept of systems as described in Figure 4. Modification of the system configuration will lead to changes in the instantaneous design capacities required for individual systems to achieve the specified average capacity. Therefore, the following instantaneous design capacities should be considered preliminary guidance which is modified as design configurations change, using the methodology and operating efficiency factors described above. 
WHC-SD-SNF-TI-016, Rev 0

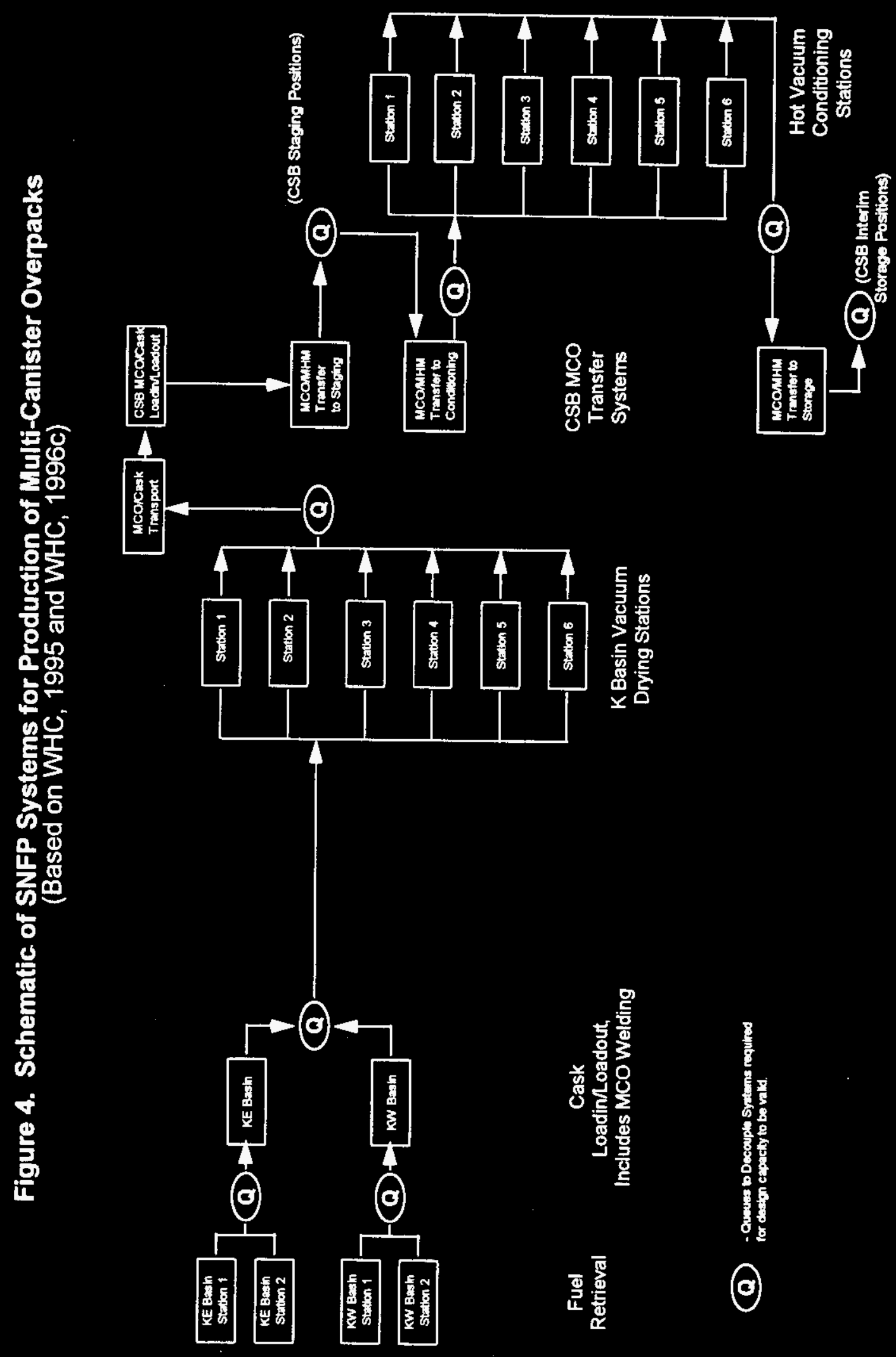




\subsubsection{Capacity of Basin Specific Systems}

The design capacity currently estimated to be required for systems specific to an individual basin are summarized in Table 5. Based on the assumptions in Table 4, systems in each bas in are required to achieve an average capacity of $0.5 \mathrm{MCO} / \mathrm{av}$ day. As indicated in Figure 4, parallel stations are assumed to be installed in each basin for fuel retrieval, feeding a single cask

loadin/loadout system. Based on the TOE factors in Table 3, the design capacity required for each fuel retrieval station is 0.37 MCO/Op day and 1.04 MCO/op day for cask loadin/loadout. The est imates for the current system configuration indicate that each fuel retrieval station (two in each basin, for a total of four) should be designed to produce the equivalent of 0.4 MCO/op day and cask loadin/loadout cycle times will need to be approximately 24 hrs (including welding of the MCO shield plug).

Capacity estimates for sludge removal and debris removal systems are not included in Table 5 at this time. The capacity of these systems could not be directly related to the MCO production rate due to the presence of material inventories which are independent from the quantity of fuel. Similarly, the water treatment system design capacity is not directly related to the ico production rate, but incorporated in the TOE estimate for In-Basin activities.

\subsubsection{Capacity of Systems Common to Both Basins}

The design capacity currently estimated to be required for systems that process MCOS from both basins are summarized in Table 6 . The average capacity required from these systems are also derived from Table 4. The number of parallel stations incorporated in each system is currently assumed to range from one to six, as indicated in Figure 4 . Based on the TOE factors in Table 3 , the design capacity required for the vacuum drying system is $1.01 \mathrm{MCO} / \mathrm{Op}$ day and $0.66 \mathrm{MCO} / \mathrm{op}$ day for the hot vacuum conditioning system. This rounds to approximately 1 MCO/op day for Cold Vacuum Drying and 0.7 MCO/op day for Hot Vacuum Conditioning.

The individual stations within the vacuum drying system can support a maximum cycle time of up to 140 hrs to produce a MCO. Each hot vacuum conditioning station can support a maximum of up to 205 hrs to produce a MCO. These cycle times would be reduced if processing stations are used for queues as suggested in Section 6.3.

The CSB system estimates are complicated by the lack of an obvious queue between cask transport, cask loadin/loadout, and the MCO Handling Machine (MHM) transfer to staging. In addition, the MHM represents a special case of the capacity analys is in that this single system may be required to support three separate transfers once the hot vacuum conditioning systems are operating. The cask transportation, loadin/loadout and MHM transfer to staging can be treated as three systems in series. Based on the operating efficiencies in Table 3 , a design capacity of $2.07 \mathrm{MCO} / 0 \mathrm{p}$ day is required for cask transport and the CSB MCO/Cask loadin/loadout systems. A total capacity to move MCOs in the MHM of $3.91 \mathrm{MCO} / \mathrm{Op}$ day is est imated. These estimates round to design capacities of 2 MCO/Op day for cask transport and CSB cask loadin/loadout. The design capacity for transfer of MCOs in the MHM is estimated at $4 \mathrm{MCO} / \mathrm{Op}$ day. 
Table 5. Calculated Design Capacities for Basin Specific Systems

\begin{tabular}{|c|c|c|c|c|c|c|}
\hline System & $\begin{array}{l}\text { Average } \\
\text { Capacity } \\
\text { (ALO/av day) }\end{array}$ & $\begin{array}{l}\text { Single } \\
\text { System } \\
\text { ToE }\end{array}$ & $\begin{array}{l}\text { Assumed Number } \\
\text { of Parallel } \\
\text { stations }\end{array}$ & $\begin{array}{l}\text { System } \\
\text { TOE }\end{array}$ & $\begin{array}{l}\text { System Design } \\
\text { Capacity } \\
\text { (MCO/op day) }\end{array}$ & $\begin{array}{l}\text { Single Station } \\
\text { Design Capacity } \\
\text { (MCO/day) }\end{array}$ \\
\hline $\begin{array}{l}\text { KW Basin Systens: } \\
\text { Debris Removal } \\
\text { Sludge Removal } \\
\text { Uater Treatment } \\
\text { Fuel Retrieval } \\
\text { Cask Loadintoadout } \\
\text { (includes HCo melding) }\end{array}$ & $\begin{array}{c}7 \\
\vdots \\
0.5 \\
0.5\end{array}$ & $\begin{array}{l}48 \% \\
48 \% \\
95 \% \\
438 \\
48 \%\end{array}$ & $\begin{array}{l}* \\
* \\
2 \\
1\end{array}$ & $\begin{array}{c}r \\
* \\
* \\
68 \% \\
48 \%\end{array}$ & $\begin{array}{c}* \\
* \\
* \\
0.74 \\
1.04\end{array}$ & $\begin{array}{c}* \\
* \\
0.37 \\
1.04\end{array}$ \\
\hline $\begin{array}{l}\text { KE Basin Systems: } \\
\text { Debris Removal } \\
\text { Sludge Removal } \\
\text { Water Treatment } \\
\text { Fuel Retrieval } \\
\text { Cask Loadinloadout } \\
\text { (incl ludes nco welding) }\end{array}$ & $\begin{array}{c}z \\
* \\
x \\
0.5 \\
0.5\end{array}$ & $\begin{array}{l}48 x \\
48 \% \\
95 \% \\
438 \\
48 \%\end{array}$ & $\begin{array}{l}8 \\
\vdots \\
2 \\
1\end{array}$ & $\begin{array}{c}r \\
* \\
68 \% \\
48 \%\end{array}$ & $\begin{array}{c}* \\
* \\
0.74 \\
1.04\end{array}$ & $\begin{array}{c}* \\
\star \\
0.37 \\
1.04\end{array}$ \\
\hline
\end{tabular}

Notes Average Capacity from Table ${ }^{4}$.
Single system To from Table 3 .

. Capacity not calculated as system capacity is not related to MCO production rate by a simple relation. 
WHC-SD-SNF-TI-016, Rev 0

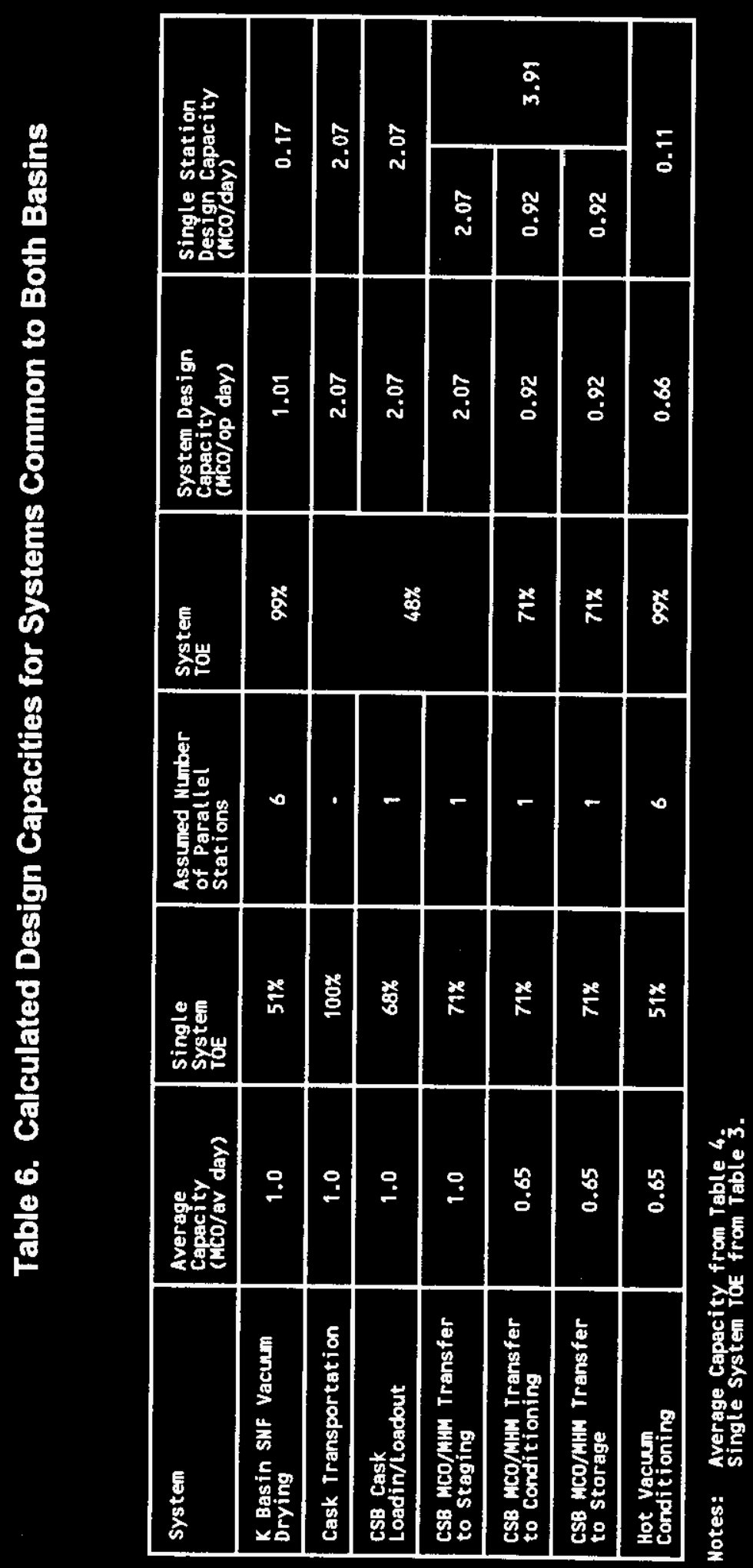


WHC-SD-SNF-TI-016, Rev, 0

\subsection{Impact of Configuration Changes on Required System Design Capacity}

As indicated above, modification of the system configuration will change the required design capacity for system elements. Figure 5 was developed as an illustration of the potential effect of configuration changes using the fuel retrieval, cask loadin/loadout, and MCO welding as an example. For the example, two different configurations are evaluated. Each configuration is required to produce $0.5 \mathrm{MCO} / \mathrm{av}$ day from bas in specific systems or $1.0 \mathrm{MCO} / \mathrm{av}$ day from systems common to both basins. In the first configuration, one MCO welding system is assumed located in each basin and included as part of the cask loadin/loadout (as indicated in Figure 4). This requires that the MCO welding, combined with cask loadin/loadout, be performed in approximately 23 hrs for each MCO.

In the second configuration, MCO welding has been decoupled from the cask loadin/loadout system and modeled as two independent systems in parallel. Modified TOEs from Table 3 for cask loadin/loadout without MCO welding and MCO welding decoupled from cask loadin/loadout are used to est imate design capacities in the second configuration. The revised estimate indicates that cask loadin/loadout could be designed to handle $0.93 \mathrm{MCO} / \mathrm{op}$ day (cycle time of 26 hrs) in each basin and the MCO welding system would require a design capacity of $1.37 \mathrm{MCO} / \mathrm{Op}$ day. Each MCO welding station would need to be designed at a capacity of $0.69 \mathrm{MCO} / \mathrm{Op}$ day, or have a maximum cycle time of 35 hrs to produce a MCO.

\subsection{Importance of Queues on the Design Basis Capacity}

Each of the design capacity estimates in Tables 5 and 6 rely on the assumption that queues are provided between major process systems such that delays in one process operation do not immediately impact other activities. Figure 6 presents an example illustrating the importance of this assumption based the fuel retrieval and cask loadin/loadout systems. For each example, an average capacity of $0.5 \mathrm{MCO} / \mathrm{av}$ day is assumed to be required for these basin specific systems. In the first example, a queue is assumed to exist between fuel retrieval and cask loadin/loadout. A design capacity of approximately $1 \mathrm{MCO} / \mathrm{Op}$ day is required for both fuel retrieval and cask loadin/loadout in this situation.

The second example is based on the same two systems without a queue. In this case, the fuel retrieval and cask loadin/loadout systems are assumed to perform as two systems in series, reducing the combined TOE. The design capacity for this system to satisfy the required average capacity of $0.5 \mathrm{MCO} / \mathrm{av}$ day is approximately $2.4 \mathrm{MCO} / \mathrm{op}$ day, reflecting the potential for operating delays in each system stopping production in the other.

The queues segregating major systems from one another do not necessarily need to be specific areas set aside only for queuing. Additional parallel stations can also effectively provide this capability. Actual methods for queuing and the queue size required to effectively allow independent operation of each major system should be established by more detailed design studies as the system configuration evolves. Table 7 provides a list of potential methods for providing queues based on the current system configuration in Figure 4. 


\section{Figure 5. Example of System Configuration Influence on Capacity Requirements}

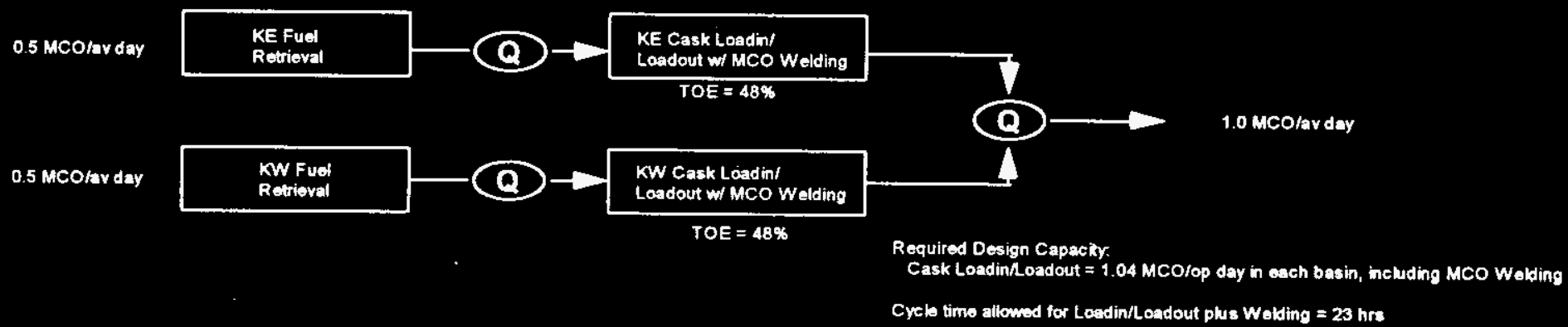

0.5 mco/avd dis

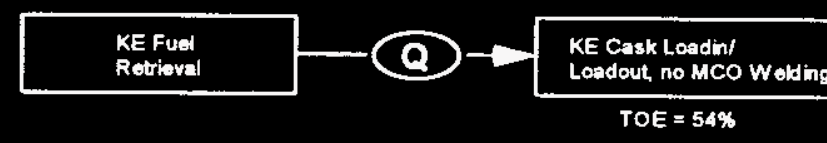

0.5 meo/arday

Retioval Loadout, no MCO Welding

TOE $=54 \%$

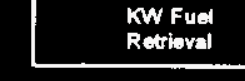

(Q) $\rightarrow$

$$
\text { TOE }=54 \%
$$

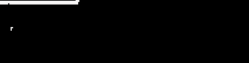

\section{TOE System $=73 x$}

Requirod Design Capacity

1.37colop day in each busin

Cuch

Cyclo tima allowed for Loadinh Loadout $=28$ hrs
Cycto time allowed for Wolding $=35$ hrs in each station 
WHC-SD-SNF-TI-016, Rev 0
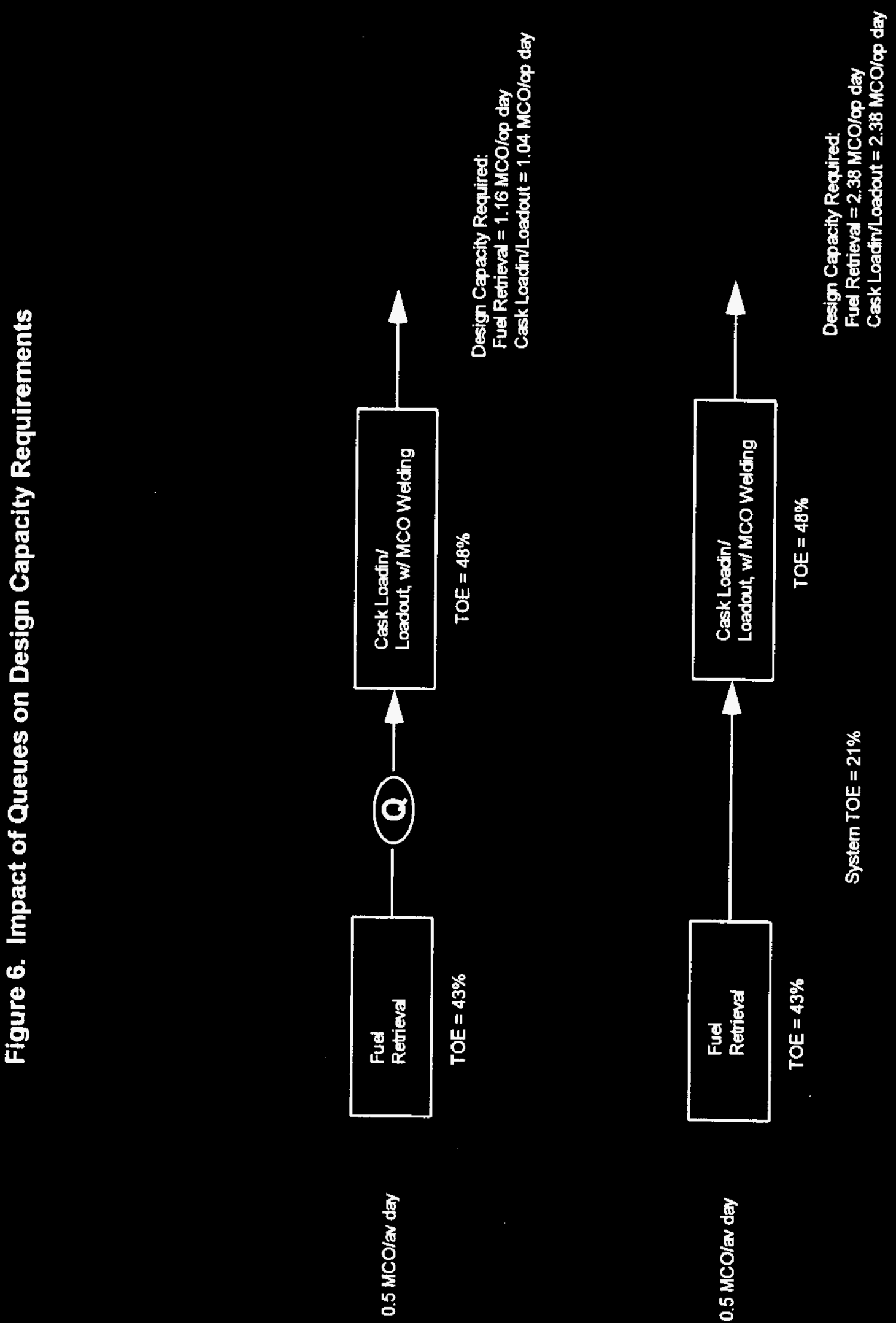

$\frac{7}{8}$
$\frac{10}{8}$
$\frac{0}{2}$
0
0 
WHC-SD-SNF-TI-016, Rev. 0

Table 7. Potential Methods of Providing Queues between Process Systems

\begin{tabular}{|l|l|l|}
\hline \multicolumn{1}{|c|}{ System Feeding Queue } & System Emptying Queue & $\begin{array}{l}\text { Method to Provide Queue } \\
\text { Capability }\end{array}$ \\
\hline \hline Fuel Retrieval & Cask Loadin/Loadout & $\begin{array}{l}\text { Fuel Baskets Staged in } \\
\text { Basin }\end{array}$ \\
\hline Cask Loadin/Loadout & Vacuum Drying & $\begin{array}{l}\text { Additional Vacuum Drying } \\
\text { Stations }\end{array}$ \\
\hline Vacuum Drying & Cask Transportation & $\begin{array}{l}\text { Additional Vacuum Drying } \\
\text { Stations }\end{array}$ \\
\hline $\begin{array}{l}\text { MCO/MHM Transfer to } \\
\text { Staging }\end{array}$ & $\begin{array}{l}\text { MCO/MHM Transfer } \\
\text { Conditioning }\end{array}$ & CSB Staging Vault Tubes \\
\hline $\begin{array}{l}\text { MCO/MHM Transfer to } \\
\text { Conditioning }\end{array}$ & Hot Vacuum Conditioning & $\begin{array}{l}\text { Additional Conditioning } \\
\text { Stations }\end{array}$ \\
\hline $\begin{array}{l}\text { Hot Vacuum Conditioning } \\
\text { Storage }\end{array}$ & $\begin{array}{l}\text { Mdransfer to } \\
\text { Stitional Conditioning } \\
\text { Stations }\end{array}$ \\
\hline $\begin{array}{l}\text { MCO/MHM Transfer to } \\
\text { Storage }\end{array}$ & - & $\begin{array}{l}\text { CSB Interim Storage } \\
\text { Vault Tubes }\end{array}$ \\
\hline
\end{tabular}




$$
\text { WHC-SD-SNF-TI-016, Rev. } 0
$$

\subsection{REFERENCES}

Rudd, 1968 Rudd, D.F. and C.C. Watson, "Strategy of Process Engineering," John Wiley \& Sons, New York, 1968.

WHC, 1995 H-2-825868, (Rev 0), SNF Project Level 0 Process Flow Diagram, dated December 15, 1995.

WHC, 1996a Letter, \# 9650036, J. A. Swenson to E. D. Sellers, "Transmittal of Integrated Process Strategy Change Request," dated January 5 ,
1996.

WHC, 1996b WHC-IP-0069, (Rev 168), K. R. Morris, "KE Basin Metal Storage and Bucket Details - and - KM Basin Metai Storage and Bucket Details," January 1996.

WHC, 1996C WHC-SD-SNF-PD-011, (Rev 0), B. L. Debban, "Spent Nuclear Fuel Project Operational Staffing Plan," January 1996. 


\section{DISTRIBUTION SHEET}

\begin{tabular}{|c|c|c|c|c|c|}
\hline \multirow{2}{*}{$\begin{array}{l}\text { To } \\
\text { Distribution }\end{array}$} & \multirow{2}{*}{\multicolumn{3}{|c|}{$\begin{array}{l}\text { From } \\
\text { Process Engineering }\end{array}$}} & \multicolumn{2}{|l|}{ Page 2 of 2} \\
\hline & & & & \multicolumn{2}{|c|}{ Date $2 / 27 / 96$} \\
\hline \multirow{2}{*}{\multicolumn{4}{|c|}{$\begin{array}{l}\text { Project Title/Work Order } \\
\text { Development of Design Basis Capacity for SNF Project Systems }\end{array}$}} & \multirow{2}{*}{\multicolumn{2}{|c|}{$\begin{array}{ll}\text { EDT No. } 612992 \\
\text { ECN No. }\end{array}$}} \\
\hline & & & & & \\
\hline \multicolumn{2}{|l|}{ Name } & $\begin{array}{c}\text { Text } \\
\text { With All } \\
\text { Attach. }\end{array}$ & Text Only & $\begin{array}{l}\text { Attach./ } \\
\text { Appendix } \\
\text { Only }\end{array}$ & $\begin{array}{l}\text { EDT/ECN } \\
\text { Only }\end{array}$ \\
\hline
\end{tabular}

F. J. Muller

C. T. O'Neill

R. P. Omberg

A. L. Pajunen

T. R. Pauly

D. R. Precechtel

G. W. Reddick

M. A. Reilly

J. I. Rivera

J. B. Roberts

T. J. Ruane

D. L. Schiffer

J. P. Schmidt

P. A. Scott

D. L. Sherre11

E. J. Shen

P. K. Shen

S. M. Short

D. W. Siddoway

S. A. Si inn

D. W. Smith

K. E. Smith

J. A. Swenson

D. S. Takasumi

C. A. Thompson

X3-85 $X$

G3-17 $X$

R3-85 $X$

R3-86 $X$

X3-85

R3-48

H5- 49

R3-86

R3-86

$\times 3-74$

$\times 3-65$

$\times 3-74$

$\times 3-78$

R3-87

R3-86

R3-86

R3-87

R3-87

X3-71

X3-74

R3-11

R3-85

R3-11

X3-85

R3-85

D. J. Tompkins

$\times 3-74$

$\times 3-80$

J. T. Vistica

G. S. Voyles

T. Webster

X3-85

J. C. Wiborg

R3-86

M. J. Wiemers

R3-86

W. L. Will is

X3-85

R3-86

J. C. Womack

R3-86

R. M. Yanochko

T. L. Yount

R3-86

R3-85

SNF Project File

Central Tiles

R3-11

A3-88 $2+029$ 


\begin{tabular}{|c|c|c|c|c|c|c|}
\hline \multicolumn{7}{|c|}{ DISTRIBUTION SHEET } \\
\hline \multirow{2}{*}{$\begin{array}{l}\text { To } \\
\text { Distribution }\end{array}$} & \multirow{2}{*}{\multicolumn{4}{|c|}{$\begin{array}{l}\text { From } \\
\text { Process Engineering }\end{array}$}} & \multicolumn{2}{|c|}{ Page 1 of 2} \\
\hline & & & & & \multicolumn{2}{|c|}{ Date $2 / 27 / 96$} \\
\hline \multirow{2}{*}{\multicolumn{5}{|c|}{$\begin{array}{l}\text { Project TitleMork Order } \\
\text { Development of Design Basis Capacity for SNF Project Sys }\end{array}$}} & \multicolumn{2}{|c|}{ EDT No. 612992} \\
\hline & & & & & \multicolumn{2}{|c|}{ ECN No. N/A } \\
\hline Name & & MSIN & $\begin{array}{c}\text { Text } \\
\text { With All } \\
\text { Attach. }\end{array}$ & Text Only & $\begin{array}{c}\text { Attach./ } \\
\text { Appendix } \\
\text { Only }\end{array}$ & $\begin{array}{l}\text { EDT/ECN } \\
\text { Only }\end{array}$ \\
\hline
\end{tabular}

C. J. Alderman

B. Baston

K. H. Bergsman

F. W. Bradshaw

D. C. Bryson

B. S. Carlisle

D. L. Chase

D. M. Chenault

R. G. Cowan

R. Cramond

J. B. Crystal

G. E. Culley

W. P. Dana

K. D. Daschke

B. L. Debban

D. R. Duncan

J. R. Frederickson

W. A. Frier

W. D. Gallo

E. W. Gerber

T. Ghigleri

L. H. Goldmann

C. S. Haller

R. M. Hiege 1

B. J. Hutchins

J. J. Irwin

A. T. Kee

R. J. Kuhta

J. M. Kurta

M. J. Langevin

C. D. Lucas

M. K. Mahaffey

J. D. Mathews

R. L. McCormack

D. W. Medford

M. A. Meier

G. R. Mezger

C. T. Miller II

W. C. Mills

W. J. Millsap

C. R. Miska

F. W. Moore

\begin{tabular}{|c|}
\hline $\begin{array}{l}\text { R3-48 } \\
\text { R3-82 } \\
\text { R3-48 } \\
\text { R3-85 } \\
\text { S7-41 } \\
\text { R3-85 } \\
\text { X3-85 } \\
\text { R3-886 } \\
\text { R3-86 } \\
\text { R3-86 } \\
\text { X3-85 } \\
\text { R3-86 } \\
\text { G3-05 } \\
\text { R3-85 } \\
\text { R3-85 } \\
\text { R3-86 } \\
\text { R3-86 } \\
\text { X3-74 } \\
\text { R3-85 } \\
\text { R3-86 } \\
\text { R3-86 } \\
\text { R3-86 } \\
\text { X3-75 } \\
\text { S7-41 } \\
\text { X3-74 } \\
\text { R3-85 } \\
\text { R3-86 } \\
\text { X3-76 } \\
\text { X3-74 } \\
\text { X3-74 } \\
\text { X3-67 } \\
\text { R3-85 } \\
\text { X3-61 } \\
\text { R3-86 } \\
\text { X3-74 } \\
\text { X3-74 } \\
\text { S7-41 } \\
\text { X3-72 } \\
\text { R3-85 } \\
\text { X3-85 } \\
\text { R3-86 } \\
\text { X3-85 }\end{array}$ \\
\hline
\end{tabular}

